\title{
FinAnCE, CONTROL, AND PROFITABILITY: THE INFLUENCE OF GERMAN BANKS
}

\author{
ROBERT S. CHIRINKO \\ JULIE ANN ELSTON
}

CESIFO WORKING PAPER NO. 1073

CATEGORY 9: INDUSTRIAL ORGANISATION

NOVEMBER 2003

An electronic version of the paper may be downloaded

- from the SSRN website: Www.SSRN.com

- from the CESifo website: www.CESifo.de 


\title{
FinANCE, CONTROL, AND PROFITABILITY: THE INFLUENCE OF GERMAN BANKS
}

\begin{abstract}
Bank intermediated finance has been cited frequently as the preferred means for channeling funds from savers to firms. Germany is the prototypical economy where universal banks allegedly exert substantial influence over firms. Despite frequent assertions about the considerable power of German banks and the advantages of a bank relation, empirical support is mixed. With a unique dataset and a focus on the fragility/sturdiness of inferences, this paper evaluates German bank influence in terms of three hypotheses: 1) do bank influenced firms enjoy lower finance costs? [No]; 2) is bank influence a solution to control problems? [Yes]; 3) do bank influenced firms have higher profitability? [No]. Coupled with results about the control consequences of concentrated ownership, these results suggest that bank influence serves as a substitute control mechanism, one of several available for addressing corporate control problems.
\end{abstract}

JEL Classification: G21, G32, G34.

Keywords: German banks, corporate finance and governance.

Robert S. Chirinko
Department of Economics
Emory University
Atlanta, GA 30322-2240
USA
rchirin@emory.edu

\author{
Julie Ann Elston \\ Department of Economics \\ College of Business Administration \\ University of Central Florida \\ Orlando, Florida 32816-1400 \\ USA \\ julie.elston@bus.ucf.edu
}

\footnotetext{
The authors acknowledge very helpful discussions with and comments from three anonymous reviewers, Horst Albach, George Benston, Wendy Carlin, Robert Carpenter, Jeremy Edwards, Michael Funke, Mike Gibson, Tim Guinnane, Craig Hakkio, Bronwyn Hall, Martin Hellwig, Tim Jenkinson, Ross Levine, Reiner König, Paul Rubin, Dorothea Schaefer, Frank Seger, Alfons Weichenrieder, Peter Zweifel, and seminar participants at the American Economic Association, American Institute of Contemporary German Studies, the California Institute of Technology, Cambridge, the Center for Economic Studies (Munich), The Comparative Institutional Analysis Seminar (Stanford), the Conference On Bank-Firm Relationships: Theory and Evidence From An International Perspective (Wissenschaftszentrum Berlin Für Sozialforschung, WZB), Emory, the European Economic Association, the Federal Reserve Bank of Kansas City, Georgia State, the Hamburg Institute For Economic Research, the London Business School, the Swiss National Bank, the Western Economic Association, and Zurich. A special note of thanks is due to our discussants, Colin Mayer and Raghu Rajan. The authors also thank Clint Cummins and Andrew Meyer for technical advice, Rudolf Schmitz for assistance in obtaining some of the data, and Yongduk Pak for his timely and expert research assistance. Partial financial support by the WZB and Emory (under a URC grant) is gratefully acknowledged. All errors, omissions, and conclusions remain the sole responsibility of the authors.
} 


\section{Article Outline}

\section{Introduction}

2. The Data

1. The Bonn Database

2. Bank Influence and Ownership Concentration

3. Data Transformation

4. Sample Characteristics

3. The Finance Hypothesis

1. Direct

1. Testable Implications

2. Empirical Results

2. Indirect

1. Testable Implications

2. Empirical Results

4. The Control Hypothesis

1. Testable Implications

2. Empirical Results

5. The Profitability Hypothesis

1. Testable Implications

2. Empirical Results

6. Summary and Conclusions

\section{Appendix}

\section{References}




\section{Introduction}

Channeling funds from savers to firms is one of the central problems facing an economy. In a frictionless world with widely-dispersed and reliable information, financial assets are perfect substitutes, and are allocated independently of existing financial markets and intermediaries. In this case, the institutional structure of the financial system is merely a veil. Recent research casts serious doubt on this frictionless model because of implausible assumptions about the availability and quality of information. In the presence of asymmetric information, financial structure has major impacts on the allocation of funds, the pace of capital formation, and the performance of the economy.

When lenders and firms face significant information asymmetries that create possibilities for opportunism by better-informed firms, banks may play an important role in financing and governing firms. Owing to economies of scale and scope, banks are arguably well-positioned to finance and monitor firms. Germany is the prototypical economy where universal banks, which offer a wide-range of financial services, allegedly exert substantial influence over firms, and thus Germany is ideal for studying bank-firm relations and bank intermediated finance. ${ }^{2}$ The current study extracts testable implications from the German Bank Influence Model (GBIM), and evaluates these hypotheses empirically.

The widely-held view of German bank influence has three major components:

\footnotetext{
${ }^{1}$ For surveys of parts of this voluminous literature, see Bernanke (1993), Brennan (2001), Hellwig (1991), and Hubbard (1998).

${ }^{2}$ Banks are important in two other G-7 countries -- France and Japan. Germany is the preferred country to explore bank influence because the role of banks is more dominant than in France. While banks play a substantial role in Japan, the use of bank finance "...has been largely a regulatory phenomenon" (Hodder and Tschoegl, 1992, p. 9), and a bank can hold only 5\% of a firm's equity (this limit was 10\% prior to 1987).
} 
finance, control, and profitability (cf. Edwards and Fisher, 1994, Chapter 1). German banks allegedly supply finance relatively cheaply because of technical expertise and superior information. The latter follows from bank representation on firms' supervisory boards and long-term relations between banks and firms. The second component of German bank influence is that banks reduce managerial agency costs associated with corporate control. The superior information that lowers finance costs also permits banks to monitor management effectively. In addition to representation on supervisory boards, banks have substantial voting power obtained either directly through ownership or indirectly through proxies, borrowings, or investment companies. Consolidated voting power, supervisory board representation, and long-term relations combine to provide banks with the potential to substantially influence firms. German banks thus would appear to have the power to solve the agency problem at the core of the corporate control dilemma and, with large ownership stakes, the incentive to exercise control. In turn, lower finance costs for external funds and lower agency costs of corporate control have a favorable effect on firm profitability, the third component of the GBIM.

While these arguments are certainly reasonable, and perhaps even persuasive, alternative perspectives exist, and the GBIM needs to be evaluated empirically. Several studies have pointed to positive roles that banks play in the success of the German system of investment finance. This confidence has not gone unchallenged. Deeg (1992, p. 3) argues that "the capacity of the German banks to influence the decisions of non-financial firms and coordinate the activities of industry is significantly more circumscribed than is widely assumed..." Wenger (1992 and with Kaserer, 1998) has written extensively on the deleterious effects of German banks. Perlitz and Seger (1994) and Seger (1997) find a negative influence of banks on firm performance. In a recent and important book, Edwards and Fischer (1994, p. 240) conclude that "The commonly-held view of the merits of the German system of finance for investment, in 
terms of the supply of external finance to firms and corporate control, receives no support from the analysis of available evidence."

However, most existing empirical work on Germany is based on relatively aggregate data or single cross-sections. In her review of Edwards and Fischer's book, Elston (1995) notes that much of the debate on the merits of the bank-based vs. marketbased finance has stagnated simply due to lack of detailed empirical evidence. Gorton (1995) expresses a similar concern, and calls for the use of firm-level cross sections to assess the influence of German banks. Studies based on cross-tabulations of aggregate financial data, while informative, can not capture the complexities affecting financing choices. There are many non-bank factors that vary across firms and influence financing decisions. Failing to control for these factors can seriously bias inferences based on aggregated data. Thus, micro-data are needed to assess the nature and extent of German bank influence.

This paper presents such a microeconomic inquiry by extracting testable implications from the GBIM. Section 2 describes the financial statement and ownership data for German firms. These panel data are transformed into a crosssection, and we discuss the econometric reasons for focusing on cross-section information.

The finance, control, and profitability hypotheses are examined in Sections 3-5 in terms of three questions: 1) do bank influenced firms enjoy lower finance costs?; 2) is bank influence a solution to control problems?; 3) do bank influenced firms have higher profitability? Apart from a standard regression analysis, we also use Leamer's Extreme Value Analysis to assess the fragility/sturdiness of our inferences and to address concerns about multicollinearity and equation specification. We find that bank influence is not associated with a reduction of finance costs nor a change in profitability. Our empirical evidence offers little support for the GBIM. Rather a view of bank relations emerges where banks provide corporate control services and are 
compensated by charging higher rates for borrowed funds and fees for a variety of other banking services. As discussed in Section 6, bank influence seems to serve as a substitute control mechanism, one of several available for addressing corporate control problems that does not appear to offer any net advantage to firms.

This inquiry should be viewed as exploratory for several reasons. The GBIM is a collection of plausible economic relations and behavioral responses, but is not based on a fully articulated model of optimizing agents constrained by information and agency problems and market forces. Thus, we are reporting some interesting conditional correlations, not identifying deep structural links. Moreover, we have not accounted for the possible endogeneity of bank affiliations. As emphasized by Demsetz and Lehn (1985), control mechanisms may be selected on the basis of particular characteristics of firms and their governance problems. While we control for several of these factors, we can not entirely discount the possibility of endogeneity bias. Notwithstanding these concerns, explicit testing of the GBIM will be useful in generating a dialogue between empirical results and theoretical models. Indeed, some of the testable propositions require auxiliary assumptions that have not been fully appreciated in the literature. The goal of the current paper is to begin to develop micro-based empirical evidence that will inform views of corporate finance and governance problems and the possibly ameliorative role of close bank relations. 


\section{The Data}

An important innovation in the current study is the unique data used to examine bank influence in Germany. Data are available for 91 firms (a listing is presented in the Appendix), and are drawn from financial statements and measures of ownership concentration. These data are described in the first two sub-sections. The final two sub-sections discuss the transformation of the data and sample characteristics.

\subsection{The Bonn Database}

The Bonn Database contains financial information on German industrial corporations quoted on the German stock exchange. ${ }^{3}$ The Database is constructed from annual business reports of unconsolidated listed firms and the annual volumes (19651990) of the Handbuch Der Aktiengesellschaften and the Statistisches Jahrbuch. The specific variables drawn from the Bonn Database and listed in the tables are defined as follows:

BANKDEBT $=\quad \begin{aligned} & \text { Long-term bank debt (maturities } \geq \text { five years) not secured by } \\ & \text { mortgages divided by TOTALASSETS. }\end{aligned}$

BANKDEBT $^{\prime}=$ Long-term bank debt (maturities $\geq$ five years) not secured by mortgages divided by long-term debt (maturities $\geq$ five years).

DIVIDENDS $=$ Dividends on common and preferred equity divided by TOTALASSETS (multiplied by 100).

FIXED $=$ Fixed assets less depreciation divided by TOTALASSETS.

\footnotetext{
${ }^{3}$ All but one of the firms is organized as an AG. The designation "AG" (Aktiengesellschaft, stock corporation) in Germany is comparable to "LTD" in the United Kingdom and "INC" in the United States. One firm is a KGaA (Kommanditgesellschaft auf Aktien), a hybrid between a limited liability partnership and a stock corporation with tradable shares. See Edwards and Fischer (1994, Chapter 4) for more information about the legal forms of enterprises in Germany.
} 
GROWTH $=$ Investment in fixed assets divided by the replacement cost of fixed assets.

ICOVERAGE $=$ The inverse of the coverage ratio (cash flow divided by total interest expenses, with cash flow defined as before-tax income plus depreciation).

LEVERAGE $=$ The book value of all of the firm's liabilities (long-term, maturities $\geq$ five years; medium-term, maturities $\geq$ one year but $<$ five years; and short-term, maturities $<$ one year) divided by TOTALASSETS.

LT-DEBT = Long-term debt (maturities $\geq$ five years) divided by TOTALASSETS.

MARKET/BOOK $=$ The market value of equity (the number of shares outstanding at the end of the year multiplied by the year end share price) divided by the book value of equity.

NET LT-DEBT $=$ Net long-term debt, LT-DEBT - BANKDEBT.

PROFITABILITY $=$ Return on assets, equal to net income (after pension payments but before taxes) and interest expense both divided by TOTALASSETS (multiplied by 100).

SIZE $=$ An indicator variable ranging from 1 (smallest) to 4 (largest) defined by quartiles of TOTALASSETS.

TOTALASSETS $=$ The book value of all of the firm's assets less depreciation on fixed assets less Qualifying Reserves, stated in billions of Deutsche Marks.

VOLATILITY $=$ The standard deviation of cash flow (defined as before-tax income plus depreciation) divided by the mean of cash flow (i.e., the coefficient of variation of cash flow). 


\subsection{Bank Influence And Ownership Concentration}

The Bonn Database is supplemented with data on bank influence and ownership concentration obtained for 1966-1988 from company annual reports and annual issues of Wer Gehört Zu Wem and Atkienführer. Bank influence (BI) is an indicator variable measuring direct ownership by a financial institution, and is defined as follows: BI equals 1 if a national bank or a national insurance company a) holds more than $25 \%$ of the outstanding shares and no other owner holds more than $25 \%$ or b) holds more than $50 \%$ of the outstanding shares; 0 otherwise (i.e., BI equal 1 when a national bank or national insurance company holds a majority or plurality (in excess of $25 \%$ ) of the outstanding shares). ${ }^{4}$ Under German corporate law, a $25 \%$ share of voting rights is sufficient to block any major proposal at the shareholders meeting.

We can also classify the 91 firms by ownership concentration, and define the following indicator variable: CONCENTRATION equals 1 if a) a single stockholder holds more than $50 \%$ of the shares or b) a limited number (two or three) of stockholders together hold more than $75 \%$ of the shares; 0 otherwise. ${ }^{5}$ Note that CONCENTRATION is defined inclusive of financial institution ownership; consequently, a firm could be both concentrated and bank influenced.

\footnotetext{
${ }^{4}$ The data did not permit separation of banks from other financial institutions. These direct ownership data are available for each year, and hence the ownership characteristic can vary over the sample, though the variation is limited. The financial institution is identified with the category in which it appears most frequently over the sample.

${ }^{5}$ Firms are classified into one of the following six mutually exclusive categories in the original data: a) a single stockholder holds more than $75 \%$ of the shares; b) several (two or three) stockholders together hold more than $75 \%$ of the shares; c) a single stockholder holds more than $50 \%$ of the shares; d) several (two or three) stockholders together hold more than $50 \%$ of the shares; e) a single stockholder holds more than $25 \%$ of the shares; f) there exists no stockholder holding more than $25 \%$ of the shares. These ownership concentration data are available for each year, and hence the concentration characteristic of a firm can vary over the sample. The firm is identified with the category in which it appears most frequently over the sample. The indicator variable is defined as follows: CONCENTRATION $=1$ if category a), b), or c) is applicable; CONCENTRATION $=0$ otherwise.
} 


\subsection{Data Transformation}

The questions motivating this study focus on long-run differences between firms with and without bank affiliations, and hence are cross-section in nature. However, since there is variation in both the cross-section and time dimensions, one is tempted to exploit all of this variation by pooling the data and estimating a fixed-effects model. Two reasons suggest resisting this temptation. First, since bank influence changes very little over time, behavioral responses to bank influence can be identified only in the cross-section. Second, using the available time variation would necessitate specifying the temporal dynamics of the financial variables. While these dynamics are interesting in their own right, they raise specification issues that may bias estimates of the parameters of interest in this study. For example, if firms smooth earnings, then annual earnings will be a misleading measure of period t profitability; the averaging procedure used here is unaffected by this intertemporal distortion. Several of these points have been considered formally by Pesaran and Smith (1995) in a random coefficients framework with exogenous regressors. These authors establish three important properties of coefficients estimated from a cross-section model: 1) they represent the long-run average effects; 2) they are consistent for large T; and 3) they are robust to misspecification of dynamics in the underlying micro model. Furthermore, even when the model is correctly specified, they show that the fixed-effects model generates inconsistent estimates. Thus, several considerations suggest a cross-section analysis of the dataset, and all of the data have been averaged along the time dimension. ${ }^{6}$

\subsection{Sample Characteristics}

Table 1 contains the means and standard deviations of the variables used in this study. Statistics are presented for the total sample and for SIZE, an indicator variable defined by quartiles of TOTALASSETS. There are few regularities in these cross-

\footnotetext{
${ }^{6}$ For those series analyzed as ratios, the ratios are computed and then summed over time; that is, ratio ${ }_{\mathrm{i}}=$ $\Sigma_{t}\left(a_{i, t} / b_{i, t}\right)$. All of the ratios are defined so that $b_{i, t}$ is far from zero. This procedure obviates the need for price deflators, which are unavailable on a firm-specific basis.
} 
Table 1: Sample Characteristics Of 91 German Firms: 1965-1990: Means and Standard Deviations

Quartiles are determined by TOTALASSETS; the fourth quartile contains one fewer firm. BANKDEBT is long-term bank debt (maturities $\geq$ five years) not secured by mortgages divided by TOTALASSETS. BANKDEBT' ${ }^{\prime}$ is long-term bank debt (maturities $\geq$ five years) not secured by mortgages divided by long-term debt (maturities $\geq$ five years). DIVIDENDS is dividends on common and preferred equity divided by TOTALASSETS (multiplied by 100). FIXED is fixed assets less depreciation divided by TOTALASSETS. GROWTH is investment in fixed assets divided by the replacement cost of fixed assets. ICOVERAGE is the inverse of the coverage ratio (cash flow divided by interest expenses, with cash flow defined as before-tax income plus depreciation). LEVERAGE is the book value of all of the firm's liabilities (Long-Term, maturities $\geq$ five years; Medium-Term, maturities $\geq$ one year but $<$ five years; and Short-Term, maturities $<$ one year) divided by TOTALASSETS. LT-DEBT is long-term debt (maturities $\geq$ five years) divided by TOTALASSETS. MARKET/BOOK is the market value of equity (the number of shares outstanding at the end of the year multiplied by the year end share price) divided by the book value of equity. NET LT-DEBT is LTDEBT less BANKDEBT. PROFITABILITY is return on assets, equal to net income (after pension payments but before taxes) and interest expense both divided by TOTALASSETS (multiplied by 100). TOTALASSETS is the book value of all of the firm's assets less depreciation on fixed assets less Qualifying Reserves, and is stated in billions of Deutsche Marks. VOLATILITY is the standard deviation of cash flow divided by the mean of cash flow (i.e., the coefficient of variation of cash flow). BANKDEBT, BANKDEBT', DIVIDENDS, FIXED, GROWTH, ICOVERAGE, LEVERAGE, LTDEBT, MARKET/BOOK, NET LT-DEBT, and PROFITABILITY, are computed as firm ratios averaged for 1965-1990. BI, CONCENTRATION, and SIZE are qualitative variables.

$\mathrm{BI}$ equals 1 if a national bank or a national insurance company a) holds more than $25 \%$ of the outstanding shares and no other owner holds more than $25 \%$ or b) holds more than $50 \%$ of the outstanding shares evaluated from 1966-1988. CONCENTRATION equals 1 if a) a single stockholder holds more than $50 \%$ of the shares or b) a limited number (two or three) of stockholders together hold more than $75 \%$ of the shares evaluated from 1966-1988. SIZE ranges from 1 (smallest) to 4 (largest) defined by quartiles of TOTALASSETS. 
Table 1 (continued): Sample Characteristics Of 91 German Firms: 1965-1990

-- Means and Standard Deviations

Variable

(1)

(2)

(3)

(4)

(5)

\begin{tabular}{|c|c|c|c|c|c|}
\hline BANKDEBT & $\begin{array}{c}0.102 \\
(0.057)\end{array}$ & $\begin{array}{c}0.105 \\
(0.074)\end{array}$ & $\begin{array}{c}0.073 \\
(0.052)\end{array}$ & $\begin{array}{c}0.089 \\
(0.048)\end{array}$ & $\begin{array}{c}0.092 \\
(0.059)\end{array}$ \\
\hline BANKDEBT $^{\prime}$ & $\begin{array}{c}0.146 \\
(0.070)\end{array}$ & $\begin{array}{c}0.160 \\
(0.107)\end{array}$ & $\begin{array}{c}0.103 \\
(0.073)\end{array}$ & $\begin{array}{c}0.133 \\
(0.089)\end{array}$ & $\begin{array}{c}0.136 \\
(0.084)\end{array}$ \\
\hline DIVIDENDS & $\begin{array}{c}1.505 \\
(0.866)\end{array}$ & $\begin{array}{c}2.611 \\
(1.500)\end{array}$ & $\begin{array}{c}1.947 \\
(0.654)\end{array}$ & $\begin{array}{c}2.072 \\
(1.050)\end{array}$ & $\begin{array}{c}2.033 \\
(1.120)\end{array}$ \\
\hline FIXED & $\begin{array}{r}0.394 \\
(0.372)\end{array}$ & $\begin{array}{c}0.375 \\
(0.167)\end{array}$ & $\begin{array}{c}0.538 \\
(0.568)\end{array}$ & $\begin{array}{c}0.616 \\
(0.532)\end{array}$ & $\begin{array}{c}0.479 \\
(0.443)\end{array}$ \\
\hline GROWTH & $\begin{array}{c}0.172 \\
(0.060)\end{array}$ & $\begin{array}{c}0.160 \\
(0.043)\end{array}$ & $\begin{array}{c}0.155 \\
(0.070)\end{array}$ & $\begin{array}{c}0.139 \\
(0.060)\end{array}$ & $\begin{array}{c}0.157 \\
(0.059)\end{array}$ \\
\hline ICOVERAGE & $\begin{array}{c}0.344 \\
(0.304)\end{array}$ & $\begin{array}{c}0.290 \\
(0.321)\end{array}$ & $\begin{array}{c}0.244 \\
(0.228)\end{array}$ & $\begin{array}{c}0.218 \\
(0.219)\end{array}$ & $\begin{array}{c}0.275 \\
(0.272)\end{array}$ \\
\hline LEVERAGE & $\begin{array}{c}0.685 \\
(0.112)\end{array}$ & $\begin{array}{c}0.626 \\
(0.109)\end{array}$ & $\begin{array}{c}0.693 \\
(0.092)\end{array}$ & $\begin{array}{c}0.673 \\
(0.109)\end{array}$ & $\begin{array}{c}0.669 \\
(0.107)\end{array}$ \\
\hline LT-DEBT & $\begin{array}{c}0.178 \\
(0.094)\end{array}$ & $\begin{array}{c}0.158 \\
(0.047)\end{array}$ & $\begin{array}{c}0.215 \\
(0.088)\end{array}$ & $\begin{array}{c}0.203 \\
(0.065)\end{array}$ & $\begin{array}{c}0.188 \\
(0.078)\end{array}$ \\
\hline MARKET/BOOK & $\begin{array}{c}2.524 \\
(1.188)\end{array}$ & $\begin{array}{c}2.123 \\
(0.852)\end{array}$ & $\begin{array}{c}2.413 \\
(1.028)\end{array}$ & $\begin{array}{c}2.083 \\
(0.963)\end{array}$ & $\begin{array}{c}2.288 \\
(1.016)\end{array}$ \\
\hline NET LT-DEBT & $\begin{array}{c}0.077 \\
(0.106)\end{array}$ & $\begin{array}{c}0.053 \\
(0.057)\end{array}$ & $\begin{array}{c}0.143 \\
(0.098)\end{array}$ & $\begin{array}{c}0.114 \\
(0.068)\end{array}$ & $\begin{array}{c}0.096 \\
(0.090)\end{array}$ \\
\hline PROFITABILITY & $\begin{array}{c}4.479 \\
(1.157)\end{array}$ & $\begin{array}{c}5.032 \\
(1.415)\end{array}$ & $\begin{array}{c}4.579 \\
(1.149)\end{array}$ & $\begin{array}{c}4.947 \\
(1.723)\end{array}$ & $\begin{array}{c}4.762 \\
(1.374)\end{array}$ \\
\hline TOTALASSETS & $\begin{array}{c}31.7 \\
(12.5)\end{array}$ & $\begin{array}{c}96.0 \\
(30.2)\end{array}$ & $\begin{array}{c}387.3 \\
(139.0)\end{array}$ & $\begin{array}{c}2802.3 \\
(2581.9)\end{array}$ & $\begin{array}{c}807.6 \\
(1691.6)\end{array}$ \\
\hline VOLATILITY & $\begin{array}{c}0.554 \\
(0.387)\end{array}$ & $\begin{array}{c}0.517 \\
(0.263)\end{array}$ & $\begin{array}{c}0.495 \\
(0.220)\end{array}$ & $\begin{array}{c}0.521 \\
(0.212)\end{array}$ & $\begin{array}{c}0.522 \\
(0.276)\end{array}$ \\
\hline $\begin{array}{l}\text { Qualitative Variables } \\
\text { BI }\end{array}$ & 0.217 & 0.130 & 0.087 & 0.091 & 0.132 \\
\hline CONCENTRATION & 0.696 & 0.565 & 0.609 & 0.500 & 0.593 \\
\hline SIZE & 1.000 & 2.000 & 3.000 & 4.000 & 2.484 \\
\hline
\end{tabular}


tabulations. GROWTH and ICOVERAGE fall monotonically with firm size. BI declines with size over the first three quartiles, but rises slightly in the fourth quartile. Variables that are key elements in the GBIM -- BANKDEBT, NET LT-DEBT, and PROFITABILITY -- show no obvious relations to size.

\section{The Finance Hypothesis}

\subsection{Direct}

\subsubsection{Testable Implications}

According to the GBIM, banks can supply funds relatively cheaply because of their ability to reduce information problems, which are the fundamental friction between borrowers and lenders. As shareholders, banks are allowed representation on the firm's supervisory board (Aufsichtsrat), and thus they obtain useful information about the firm that is not widely available. Since banks usually hold shares over long periods of time, they have the incentive and the ability to engage in extensive and ongoing information gathering about the firm. ${ }^{7}$ Information problems are thus reduced. Coupled with their technical expertise, banks are able to offer relatively inexpensive external finance to affiliated firms. One testable implication of this outward shift in the loan supply curve is that, ceteris paribus, the balance sheets of bank influenced firms should contain a greater proportion of bank debt. ${ }^{8}$

Of course, other things are rarely equal, as many additional factors determine the amount of bank debt held by firms. For example, we might expect that bank debt is positively related to the cash flow volatility, as firms subject to sharp swings in cash flow value an ongoing bank relation and a readily available line of credit. Sorting the

\footnotetext{
${ }^{7}$ See Deeg (1992), Edwards and Fischer (1994), Mülbert (1998), Perlitz and Seger (1994), and Smith (1994) for detailed descriptions of the German banking system.

${ }^{8}$ An additional implication is that loan interest rates should be lower for bank influenced firms. Unfortunately, interest rate data are unavailable and, even if available, would need to be adjusted for loan maturity, the borrower's credit rating, and the non-price terms of lending.
} 
sample into quartiles based on cash flow volatility, we find that the ratio of bank debt to total assets (BANKDEBT) is 0.08 for firms in the first two (relatively stable) quartiles. The bank debt ratio increases to 0.09 and 0.11 for the latter two quartiles as cash flow volatility increases. The impact of cash flow volatility and other factors on the use of bank debt indicates that assessments of bank influence must condition on firm-specific characteristics to avoid biases from omitted variables. Micro-data are thus essential for generating an accurate evaluation of the GBIM.

Based on these considerations, the direct finance hypothesis is tested with the following Ordinary Least Squares (OLS) specification,

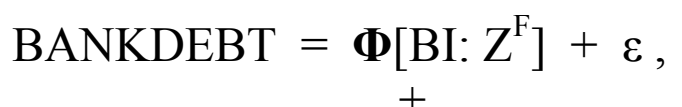

where $\mathrm{BI}$ is an indicator variable for bank influence, $\boldsymbol{\Phi}[$.$] is a linear function, \varepsilon$ is a stochastic error, and $Z^{\mathrm{F}}$ represents the set of conditioning variables necessary for evaluating the finance hypothesis: a constant, the size of the firm in terms of total assets, the growth of the capital stock, the ratio of market to book equity, the volatility of cash flow, ownership concentration, and the amount of dividends, fixed assets, and net income plus interest expense, all relative to total assets. (The sensitivity of the empirical results to variations in this lengthy list of conditioning variables is examined with an Extreme Value Analysis.) The direct finance hypothesis associated with the GBIM is evaluated by the coefficient on BI.

\subsubsection{Empirical Results}

We begin to test the direct finance hypothesis by OLS estimates of (1). Column 1 of Table 2 contains results with our measure of bank influence and the full set of conditioning variables. Focusing on coefficients statistically significant at conventional levels, we see that bank debt is higher for concentrated firms and firms with more volatile cash flow. The BI coefficient central to our evaluation of the GBIM is negative but statistically close to zero. 
Table 2: Ordinary Least Squares Regressions -- Dependent Variables: BANKDEBT Or BANKDEBT'

For all but the last two rows, the entries are based on the following Ordinary Least Squares (OLS) regression model (1): BANKDEBT (or BANKDEBT') $=\boldsymbol{\Phi}\left[\mathrm{BI}: \mathrm{Z}^{\mathrm{F}}\right]+\varepsilon$. $\boldsymbol{\Phi}[$.] is a linear function, $\varepsilon$ is a stochastic error, and $\mathrm{Z}^{\mathrm{F}}$ represents the set of conditioning variables listed in Panel B. Columns 1 and 5 use the full set of conditioning variables; columns 2 and 6 use those conditioning variables significant at the $10 \%$ level in the initial regression. The dependent variable is BANKDEBT in columns 1-4 and BANKDEBT' in columns 5 and 6. All variables are described in Table 1. Estimated coefficients are reported in the table; standard errors are in parentheses and are heteroscedastic consistent using the technique of White (1980) with a bias correction (Davidson and MacKinnon, 1993, pp. 552-554, equation $\mathrm{HC}_{2}$ ). RSS is the residual sum of squares. The remaining two entries are based on the following OLS regression model that permits both the constant term and slope coefficients to differ for bank influenced firms: BANKDEBT $=\boldsymbol{\Phi}\left[\mathrm{BI} * \mathrm{Z}^{\mathrm{F}}: \mathrm{Z}^{\mathrm{F}}\right]+\varepsilon . \Omega$ is the p-value for the F-statistic testing the null hypothesis that the interaction variables, $\mathrm{BI}^{*} \mathrm{Z}^{\mathrm{F}}$, have no effect on BANKDEBT. This statistic is distributed $F(K, N-2 K)$, where $K$ is the number of conditioning variables (including the constant term). $\Gamma$ is the percentage change in BANKDEBT with respect to an increase in $\mathrm{BI}$. For firms having $\mathrm{BI}=0, \mathrm{BI}$ is changed from 0 to 1 , and the fitted values of $\mathrm{BANKDEBT}$ are computed; for firms having $\mathrm{BI}=1, \mathrm{BI}$ is changed from 1 to 0 , the fitted values of $\mathrm{BANKDEBT}$ are computed, and are multiplied by -1 . $\Gamma$ equals the mean of the ratio of these fitted values divided by BANKDEBT. $\Omega$ and $\Gamma$ measure the statistical and economic importance, respectively, of the interaction variables. Columns 3 and 4 contain the Extreme Value Analysis (EVA) using all possible combinations of the conditioning variables. Column 3 contains the mean, standard deviation, lower bound, and upper bound of the distribution of the estimated BI coefficient. Column 4 contains the same statistics for the distribution of the associated $t$-statistic. 
Table 2 (continued): Ordinary Least Squares Regressions -- Dependent Variables: BANKDEBT (Columns 1-4) Or BANKDEBT' (Columns 5 and 6)

\begin{tabular}{|c|c|c|c|}
\hline & BANKDEBT & EVA & BANKDEBT $^{\prime}$ \\
\hline Variable & (1) & $\begin{array}{c}\text { Coefficients } \text { T-Statistics } \\
\text { (3) }\end{array}$ & (5) \\
\hline
\end{tabular}

A. Bank Influence Variable

BI

$$
\begin{array}{ll}
-0.008 & -0.012 \\
(0.017) & (0.014)
\end{array}
$$$$
(0.017) \quad(0.014)
$$

\section{Mean}

[Standard Deviation]

Minimum

Maximum

B. Conditioning Variables

Constant

$0.053 \quad 0.045$

$\begin{array}{ll}(0.039) & (0.020)\end{array}$

CONCENTRATION

DIVIDENDS

FIXED

GROWTH

MARKET/BOOK

PROFITABILITY

SIZE

VOLATILITY

Adjusted $\mathrm{R}^{2}$
$\operatorname{RSS}$
$\Omega$
$\Gamma$

$$
\begin{array}{rr}
0.027 & 0.027 \\
(0.013) & (0.011)
\end{array}
$$

$$
0.000
$$$$
\text { (0.016) }
$$

0.015

(0.019)

$-0.055$

(0.127)

$-0.005$

(0.008)

$$
\begin{array}{r}
0.005 \\
(0.009)
\end{array}
$$

$-0.008$

$(0.005)$

$$
\begin{array}{rr}
0.066 & 0.061 \\
(0.034) & (0.037)
\end{array}
$$

$$
\begin{array}{cc}
0.113 & 0.126 \\
0.251 & 0.265 \\
0.987 & 0.870 \\
-0.504 & -0.277
\end{array}
$$

$$
\begin{array}{cc}
0.006 & -0.008 \\
(0.027) & (0.025)
\end{array}
$$

$\begin{array}{ll}-0.016 & -1.067 \\ {[0.005]} & {[0.343]} \\ -0.028 & -1.802 \\ -0.005 & -0.291\end{array}$

$0.078 \quad 0.105$

(0.052) (0.028)

$0.040 \quad 0.036$

(0.019) (0.016)

0.007

(0.018)

0.032

(0.028)

$-0.075$

(0.186)

$-0.013$

(0.011)

0.008

(0.011)

$\begin{array}{ll}-0.013 & -0.007\end{array}$

(0.007) (0.007)

$0.072 \quad 0.056$

(0.036) (0.043)

$$
\begin{array}{cc}
0.093 & 0.062 \\
0.518 & 0.568 \\
0.992 & 0.910 \\
-0.453 & -0.194
\end{array}
$$


The results for BI can be sensitive to the conditioning variables included in the regression, and three further tests are undertaken. First, columns 2 presents results where the conditioning variables insignificant at the $10 \%$ level in the initial regressions are removed. In these restricted regressions, the coefficient on BI remains negative and statistically and economically insignificant.

Second, the above results allow only the constant term to shift in response to bank influence. By interacting BI with the conditioning variables, we can allow both the constant term and slope coefficients to differ for bank influenced firms, and we estimate the following model,

$$
\mathrm{BANKDEBT}=\boldsymbol{\Phi}\left[\mathrm{BI} \mathrm{Z}^{\mathrm{F}}: \mathrm{Z}^{\mathrm{F}}\right]+\varepsilon
$$

The statistical significance of the interaction variables, $\mathrm{BI} \mathrm{Z}^{\mathrm{F}}$ is assessed by an F-test, and the p-values $(\Omega)$ reported in Table 2 indicate that the bank influence variable is statistically insignificant in both regressions. Alternatively, the economic significance of the interaction variables can be assessed by calculating $\Gamma$, the percentage change in BANKDEBT when an independent firm becomes affiliated with a bank (and vice versa for bank affiliated firms). ${ }^{9}$ If bank influence leads to a substantially favorable shift in the supply curve of bank loans, $\Gamma$ will be positive and large. Instead of an outward movement, bank influence leads to a large inward shift of the supply curve, and existing loans decline substantially. Our micro-data evidence complements the findings of Corbett and Jenkinson (1998, Table 1) and Mayer (1990, Table 12.3), who show with aggregate data that Germany utilizes less bank debt than most other industrialized countries. Taken together, these results from micro and aggregate datasets raise the question as to which characteristics define a bank-based economy.

Third, the above procedures are two of several ways to conduct specification

\footnotetext{
${ }^{9}$ See the notes to Table 2 for details about the computation of $\Gamma$.
} 
searches. However, inquisitive (cynical?) readers may be left wondering whether there is some other combination of correlated regressors that might alter inferences. The structure of our research problem permits us to address this skepticism straightforwardly. The direct finance hypothesis only concerns the BI coefficient. While some of the conditioning variables may be important determinants of bank loans, the actual combination is unimportant for the hypothesis of interest. Applying the Extreme Value Analysis (EVA) proposed by Leamer (1983), we estimate (1) with all possible combinations of the conditioning variables, and report the mean, standard deviation, minimum value, and maximum value of the distribution of the estimated BI coefficient, as well as similar characteristics for the distribution of its t-statistic. In the present case with eight conditioning variables (listed in Table 2), $2^{8}=$ 256 regressions are estimated.

The results from the EVA presented in columns 3 and 4 of Table 2 corroborate the above findings. The statistics for the distribution of estimated coefficients are reported in column 3, and show that, regardless of the linear combinations of the $\mathrm{Z}^{\mathrm{F}}$ variables, it is impossible to obtain a positive coefficient on BI. The t-values in column 4 indicate that these coefficients are usually far from zero in a statistical sense.

These results are at odds with the GBIM, and suggest alternative interpretations of the bank influence/lending relation. Rajan (1992) and Sharpe (1990) have argued that the ex-post information monopoly (relative to alternative lenders) provides banks a substantial bargaining advantage that may be difficult to guard against ex-ante. In this situation, banks "holdup" firms with which they are associated, loan rates rise, and loan volume falls. Portfolio considerations further suggest that a bank with a substantial stake in a firm's equity may want to attenuate its exposure by issuing less debt to that firm. Either of these alternative scenarios implies that, ceteris paribus, the BI coefficient in (1) will be negative.

A third scenario suggests that the GBIM is valid but that our test based on the 
ratio of bank debt to total assets may be misleading. ${ }^{10}$ The problem occurs because bank influence can also lower the cost of equity. In this case, the firm's capital structure would be tilted away from debt in general and, as in Table 2, we would expect to see a negative relation between BANKDEBT and BI. We can account for this lower equity cost effect by defining BANKDEBT' as the ratio of bank debt to total debt. Results are presented in columns 5 and 6 of Table 2, and give some mild support to the equity cost hypothesis. The BI coefficients in columns 5 and 6 are slightly more positive (or less negative) than the comparable coefficients in columns 1 and 2, respectively. Nonetheless, the coefficients remain statistically close to zero.

In sum, the evidence in Table 2 provides no support for the proposition that bank affiliation directly lowers the cost of finance, and hence no support for the direct finance hypothesis associated with the GBIM.

\subsection{Indirect}

\subsubsection{Testable Implications}

A bank relation can also lower a firm's finance costs indirectly through a certification effect. Evaluating business fundamentals and monitoring firm performance entail substantial fixed costs. For most creditors, these costs are high (relative to the return on investible funds), and extending credit in a prudent fashion becomes unprofitable. However, bank affiliation can be a forceful signal of the firm's creditworthiness. Information advantages (through supervisory board representation and long-term relations), technical expertise, and direct ownership stakes enable banks to generate credible signals about a firm's creditworthiness. In the United States, James (1987) and Lummer and McConnell (1989) establish that an announcement of a new bank loan or a bank line of credit has a greater positive effect on the firm's stock price than an announcement of an alternative source of credit.

Certification lowers the cost of external funds, and is most likely to be evident

${ }^{10}$ We thank one of our reviewers for suggesting this scenario. 
for credits with lengthy maturities. If the GBIM is valid, we would expect bank influenced firms to have higher proportions of long-term debt, net of bank debt, on their balance sheets. The indirect finance hypothesis is evaluated by the coefficients on BI in the following OLS specifications,

$$
\text { NET LT-DEBT } \begin{gathered}
\boldsymbol{\Phi}\left[\mathrm{BI}: \mathrm{Z}^{\mathrm{F}}\right]+\varepsilon \\
+
\end{gathered}
$$

where NET LT-DEBT equals long-term debt net of long-term bank debt divided by total assets and the conditioning variables $\left(\mathrm{Z}^{\mathrm{F}}\right)$ are the same for both the direct and indirect finance hypotheses.

\subsubsection{Empirical Results}

The indirect financing hypothesis is examined in Table 3, which reports OLS estimates of (2). As in Table 2, column 1 utilizes the full set of conditioning variables, while column 2 uses only those conditioning variables significant initially. We find that NET LT-DEBT rises with MARKET/BOOK (as "winners" get funded more easily from outside sources) and SIZE (in accord with the consensus view noted by Harris and Raviv, 1991), and falls with VOLATILITY (as the firm becomes more risky). The BI coefficients are negative and statistically close to zero. ${ }^{11}$ The $\Omega$ statistics indicate that, in regressions where $\mathrm{BI}$ interacts with the conditioning variables, these interactions are statistically insignificant. The EVA in columns 3 and 4 of Table 3 confirms the difficulty in uncovering evidence supporting the GBIM, as the bank influence coefficient is always estimated imprecisely. The results in Table 2 indicate firmly that finance costs are not lower for firms affiliated with banks.

\footnotetext{
${ }^{11}$ If NET LT-DEBT is replaced by NET LEVERAGE (LEVERAGE less BANKDEBT), the coefficients on $\mathrm{BI}$ continue to be statistically close to zero. The only important difference is that the $\mathrm{R}^{2}$ s double.
} 
Table 3: Ordinary Least Squares Regressions -- Dependent Variable: NET LT-DEBT

For all but the last two rows, the entries are based on the following Ordinary Least Squares (OLS) regression model (2): NET LT-DEBT $=\boldsymbol{\Phi}\left[\mathrm{BI}: \mathrm{Z}^{\mathrm{F}}\right]+\varepsilon . \boldsymbol{\Phi}[$.$] is a linear function, \varepsilon$ is a stochastic error, and $Z^{\mathrm{F}}$ represents the set of conditioning variables listed in Panel B. Column 1 uses the full set of conditioning variables; column 2 uses those conditioning variables significant at the $10 \%$ level in the initial regression. All variables are described in Table 1. Estimated coefficients are reported in the table; standard errors are in parentheses and are heteroscedastic consistent using the technique of White (1980) with a bias correction (Davidson and MacKinnon, 1993, pp. 552-554, equation $\mathrm{HC}_{2}$ ). RSS is the residual sum of squares. The remaining two entries are based on the following OLS regression model that permits both the constant term and slope coefficients to differ for bank influenced firms: NET LT-DEBT $=\boldsymbol{\Phi}\left[\mathrm{BI}^{*} \mathrm{Z}^{\mathrm{F}}: \mathrm{Z}^{\mathrm{F}}\right]+\varepsilon . \Omega$ is the $\mathrm{p}$-value for the F-statistic testing the null hypothesis that the interaction variables, $B I^{*} Z^{F}$, have no effect on NET LT-DEBT. This statistic is distributed F(K,N$2 \mathrm{~K}$ ), where $\mathrm{K}$ is the number of conditioning variables (including the constant term). $\Gamma$ is the percentage change in NET LT-DEBT with respect to an increase in BI. For firms having BI=0, BI is changed from 0 to 1, and the fitted values of NET LT-DEBT are computed; for firms having BI=1, BI is changed from 1 to 0 , the fitted values of NET LT-DEBT are computed, and are multiplied by -1 . $\Gamma$ equals the mean of the ratio of these fitted values divided by NET LT-DEBT. (In one case, the mean of NET LT-DEBT is very close to zero; the resulting outlier has been removed from the $\Gamma$ statistics in columns 1 and 2.) $\Omega$ and $\Gamma$ measure the statistical and economic importance, respectively, of the interaction variables. Columns 3 and 4 contain the Extreme Value Analysis (EVA) using all possible combinations of the conditioning variables. Column 3 contains the mean, standard deviation, lower bound, and upper bound of the distribution of the estimated BI coefficient. Column 4 contains the same statistics for the distribution of the associated t-statistic. 
Table 3 (continued): Ordinary Least Squares Regressions -- Dependent Variable: NET LT-DEBT

\begin{tabular}{llll}
\hline & & EVA \\
Variable & (1) & (2) & Coefficients T-Statistics \\
\hline
\end{tabular}

A. Bank Influence Variable

BI

$-0.011-0.002$

$(0.022) \quad(0.023)$

Mean

[Standard Deviation]

Minimum

Maximum

$0.003 \quad 0.095$

[0.010] [0.400]

$-0.021 \quad-0.898$

$0.024 \quad 0.854$

B. Conditioning Variables

Constant

$\begin{array}{cc}0.039 & 0.070 \\ (0.054) & (0.034)\end{array}$

CONCENTRATION $\quad-0.026$

(0.018)

DIVIDENDS

$-0.008$

(0.009)

FIXED

$0.040 \quad 0.018$

$(0.024) \quad(0.018)$

GROWTH

0.199

(0.197)

MARKET/BOOK

$0.020 \quad 0.018$

$(0.011) \quad(0.010)$

PROFITABILITY $\quad 0.005$

$(0.008)$

SIZE

$\begin{array}{ll}0.018 & 0.019\end{array}$

$(0.008) \quad(0.008)$

VOLATILITY

$\begin{array}{ll}-0.140 & -0.135\end{array}$

$(0.032) \quad(0.031)$

$\begin{array}{lrr}\text { Adjusted } \mathrm{R}^{2} & 0.219 & 0.222 \\ \mathrm{RSS} & 0.517 & 0.541 \\ \Omega & 0.515 & 0.863 \\ \Gamma & -0.024 & 0.269\end{array}$




\section{The Control Hypothesis}

\subsection{Testable Implications}

The early corporate governance literature, as well as recent work on agency theory, has focused on the issues raised by widely-dispersed shareholdings in marketfinance economies. ${ }^{12}$ The combined demands for huge sums of capital by firms and diversified portfolios by investors results in owners who usually possess little information, expertise, or incentive to monitor or discipline management. Ideally, these agency problems between owners and managers are solved by a financial system with the proper incentives so that managers, while acting in their self-interest, behave consistent with the goals of the owners. With a widely-dispersed ownership, creating such an incentive-compatible financial system is difficult because individual owners have little inducement to monitor management performance nor fund distressed firms. That is, free-rider problems loom large. Unresolved agency problems, combined with the impossibility of writing contracts that cover all future possibilities, lead to corporate control problems (Hart, 1995).

There are several institutional arrangements for achieving corporate control. A hostile takeover by equity accumulation is one possibility. ${ }^{13}$ However, notwithstanding the recent takeovers of Mannesmann by Vodafone and Kamps by Barilla, this corporate

\footnotetext{
${ }^{12}$ See Roe (1994), Sable, Griffin, and Deeg (1993), and Zysman (1983) for historical overviews of the corporate governance literature from a political economy perspective, Roy (1997) for a critique of the economic efficiency approach from a sociological perspective, Lindberg, Campbell, and Hollingsworth (1991) for an analytic framework that combines the insights from many different social science disciplines, Hart (1995) for a theoretical overview of corporate governance issues in the context of financial economics, and Shleifer and Vishny (1997) for a recent comprehensive survey of the corporate governance literature.

${ }^{13}$ The effectiveness of hostile takeovers as a mechanism for corporate control has been questioned by empirical results for the United Kingdom (Franks and Mayer, 1996) and the United States (Martin and McConnell, 1991). Stiglitz (1985) presents theoretical arguments that hostile takeovers are not an effective control mechanism in market-finance economies. He believes that banks through the issuance of debt may be more effective in achieving corporate control.
} 
control mechanism is used rarely in Germany. ${ }^{14}$ For the period 1988-1996, there were 17 hostile takeovers in Germany. Relative to approximately 600 listed firms, hostile takeovers amount to $0.3 \%$ per year. By contrast, the United Kingdom had 320 hostile takeovers for the period January 1985 to June 1996, corresponding to a rate of $1.5 \%$ per year. $^{15}$

Four other mechanisms for corporate control may be operative in Germany. First, sufficiently concentrated ownership directly attenuates the free-rider problem, and creates incentives for owners to invest resources to address agency problems. Second, dividends can serve as a control device. For a given investment policy and cash flow, dividend payouts force management into external capital markets where control costs may be lower (Easterbrook, 1984). Third, mandatory interest payments also reduce the scope of managerial discretion, and enhance control. ${ }^{16}$

Fourth, banks may exercise a notable amount of control over the firm in several ways. As mentioned above, banks frequently hold seats on the firm's supervisory board. This representation frequently results in a banker serving as the chair. ${ }^{17}$ As members of the supervisory board, banks appoint the management board (Vorstand, whose members can not be members of the supervisory board). Bank control is further

\footnotetext{
${ }^{14}$ Kester (1992, p. 95) reports that the wave of acquisitions in the late 1980's was due in large part to a preannounced capital gains tax increase for 1990.

15 The German and United Kingdom data on hostile takeovers are from Jenkinson and Ljungqvist (2001, p. 398) and Cosh and Guest (2001, p. 7), respectively. The percentages are computed as the average number of takeovers divided by the average number of listed shares. The latter figure is difficult to estimate precisely because some listed firms are not subject to takeover due to, inter alia, their status as investment trusts (closed-end funds) or a sufficiently large ownership concentration that makes a hostile takeover virtually impossible.

${ }^{16}$ The role of debt as a control device has been studied by, among others, Grossman and Hart (1982), Harris and Raviv (1990), and Jensen (1986).

${ }^{17}$ Chairing the supervisory board is particularly important because, for AG's with more than 2,000 employees, half of the supervisory board is elected by the employees. The chair is in a position to break tie votes of the supervisory board.
} 
enhanced by voting rights exercised at the annual shareholders meeting (Hauptversammlung). Voting rights are obtained directly from ownership stakes and indirectly in three ways: through proxies from shares deposited in trustee accounts (Depotstimmrecht), ${ }^{18}$ by the lending of votes among banks (Stimmenleihe), and through shares held by investment companies owned by banks (Publikumsfonds). ${ }^{19}$ The combination of direct ownership, proxies, and other indirect ways of obtaining voting rights leads to a substantial consolidation of power. The overall proportion of voting rights exercised by banks at the 1992 shareholders meetings of the 24 largest widely held stock corporations ranged from $44 \%-99 \%$ and averaged $84 \%$. Of this latter figure, $10 \%$ is due to investment companies, $13 \%$ to direct ownership, and $61 \%$ to proxies (Baums, 1996, p. 149). Consolidated voting power, supervisory board representation, and long-term relations would appear to provide German banks with the power to solve agency problems at the core of the corporate control dilemma and, with large ownership stakes, the incentive to exercise control.

If German bank influence is a substitute control mechanism, we should find, ceteris paribus, a negative relation between bank influenced firms and one or more of the other three mechanisms for exercising corporate control. Since bank influence is measured by a binary indicator variable, the control hypothesis is examined in terms of the following probit specification,

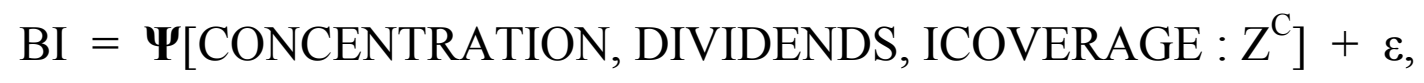

\footnotetext{
${ }^{18}$ In the 1970s, almost half of the total shares issued were deposited in such bank trustee accounts (Gessler Commission, 1979; Krummel, 1980). In 1990, more than three-quarters of the value of domestic shares held outside the Bundesbank were in the custody of private banks (Smith, 1994, p. 359).

${ }^{19}$ Unlike open-end or closed-end mutual funds in the United States, German investment companies are corporations usually owned by universal banks, and the stocks in an investment company's portfolio are voted by the owners. Stock in a parent bank held in an investment company's portfolio can be voted at the parent bank's annual meeting and, in 1992, these votes were cast uniformly in support of the proposals favored by the parent bank's management. See Baums (1996, esp. Sections 4.2.1 and 4.5.2) for an excellent introduction to German investment companies and their relations with universal banks.
} 
where $\boldsymbol{\Psi}[$.$] is a non-linear function, CONCENTRATION is ownership concentration,$ DIVIDENDS is dividends on common and preferred equity divided by total assets (multiplied by 100), ICOVERAGE is the inverse of the coverage ratio (cash flow divided by interest expenses), $\mathrm{Z}^{\mathrm{C}}$ is composed of the same conditioning variables as $\mathrm{Z}^{\mathrm{F}}$ with the exclusion of CONCENTRATION and DIVIDENDS. Negative coefficients on CONCENTRATION, DIVIDENDS, or ICOVERAGE support the hypothesis that bank influence serves as a control mechanism.

\subsection{Empirical Results}

If bank influence is a mechanism for corporate control, then, ceteris paribus, it should be negatively associated with one or more of the variables representing other corporate control mechanisms. This aspect of the GBIM is examined in the probit equations presented in Table 4. Two of the corporate control variables -- DIVIDENDS and ICOVERAGE -- are never statistically significant, even in regressions (not reported) in which either variable appears as the only corporate control variable. ${ }^{20}$

The results with CONCENTRATION, however, are striking and robust. CONCENTRATION enters significantly negative in the models in the first two columns of Table 4 . The EVA in columns 3 and 4 of Table 4 establishes the sturdiness of this inference, as it is impossible to obtain anything other than a negative sign on CONCENTRATION. Moreover, these coefficients are usually statistically significant at conventional levels. Table 4 suggests that bank influence is a substitute mechanism for controlling corporations.

CONCENTRATION also has an economically important impact on the

\footnotetext{
${ }^{20}$ However, if banks exercise control by increasing dividends or interest payments, a positive correlation between BI and DIVIDENDS or ICOVERAGE could emerge, and the negative effect of DIVIDENDS or ICOVERAGE could be masked. To explore this possible bias, we run regressions with DIVIDENDS or ICOVERAGE regressed against 1) BI and a constant, 2) BI and $Z^{C}$, and 3) $\mathrm{BI}^{*} \mathrm{Z}^{\mathrm{C}}$ and $\mathrm{Z}^{\mathrm{C}}$. The null hypothesis that the bank influence variable(s) has no effect is easily sustained.
} 
Table 4: Probit Regressions -- Dependent Variable: BI

The entries are based on the following Probit regression model (3): BI $=\boldsymbol{\Psi}[\mathrm{CONCENTRATION}$, DIVIDENDS, ICOVERAGE : $\left.Z^{\mathrm{C}}\right]+\varepsilon . \quad \Psi$.] is a non-linear function, $\varepsilon$ is a stochastic error, and $\mathrm{Z}^{\mathrm{C}}$ represents the set of conditioning variables listed in Panel B. Column 1 uses the full set of conditioning variables; column 2 uses those conditioning variables significant at the $10 \%$ level in the initial regression. All variables are described in Table 1. Estimated coefficients are reported in the table; standard errors are in parentheses. RSS is the residual sum of squares. $\Theta$ is based on the following Probit regression model that permits both the constant term and slope coefficients to differ for bank influenced firms: $\mathrm{BI}=\boldsymbol{\Psi}\left[\mathrm{CONCENTRATION} * \mathrm{Z}^{\mathrm{C}} \mathrm{Z}^{\mathrm{C}}\right]+\varepsilon . \Theta$ is the p-value for the $\log$ likelihood statistic testing the null hypothesis that the interaction variables, CONCENTRATION* $Z^{\mathrm{C}}$, have no effect on BI. (Non-linearities inherent in the probit model preclude examining interaction variables with the F-test used in Tables 2,3 , and 5.) This statistic is distributed $\chi^{2}(\mathrm{~K})$, where $\mathrm{K}$ is the number of conditioning variables (including the constant term). $\Delta+$ and $\Delta$-are based on the following Probit regression: $\mathrm{BI}=\boldsymbol{\Psi}\left[\mathrm{CONCENTRATION:} \mathrm{Z}^{\mathrm{C}}\right]+\varepsilon$, and measure the sensitivity of a firm's probability of being bank influenced to CONCENTRATION. (Since CONCENTRATION is discrete, the standard measure of sensitivity, the analytic derivative of the cumulative distribution function, is inappropriate.) The firms are divided into two groups: group one comprises those firms with CONCENTRATION=0; group two comprises those firms with CONCENTRATION=1. $\Delta_{+}$is computed with the first group of firms by changing CONCENTRATION from 0 to 1 for this subset of firms, computing the probability of a firm being bank influenced holding all other variables constant, subtracting this counterfactual probability from the probability estimated in the probit equation when CONCENTRATION $=0$, and averaging the changes across all the firms in this subset. $\Delta$ - is computed in a similar procedure but with the second group of firms and with a change in CONCENTRATION from 1 to 0 . The number in braces is the probability estimated in the probit equation when CONCENTRATION=0 (for the first group of firms) or CONCENTRATION=1 (for the second group of firms). Columns 3-6 contain the Extreme Value Analysis using all possible combinations of the conditioning variables. Columns 3 and 5 contains the mean, standard deviation, lower bound, and upper bound of the distribution of the estimated BI coefficient. Columns 4 and 6 contain the same statistics for the distribution of the associated t-statistic. Columns 3 and 4 differ from those in columns 5 and 6 in the number of firms used in the analysis: columns 3 and 4 use the full sample including firms controlled by national enterprises, while columns 5 and 6 excludes these firms. 
Table 4 (continued): Probit Regressions -- Dependent Variable: BI

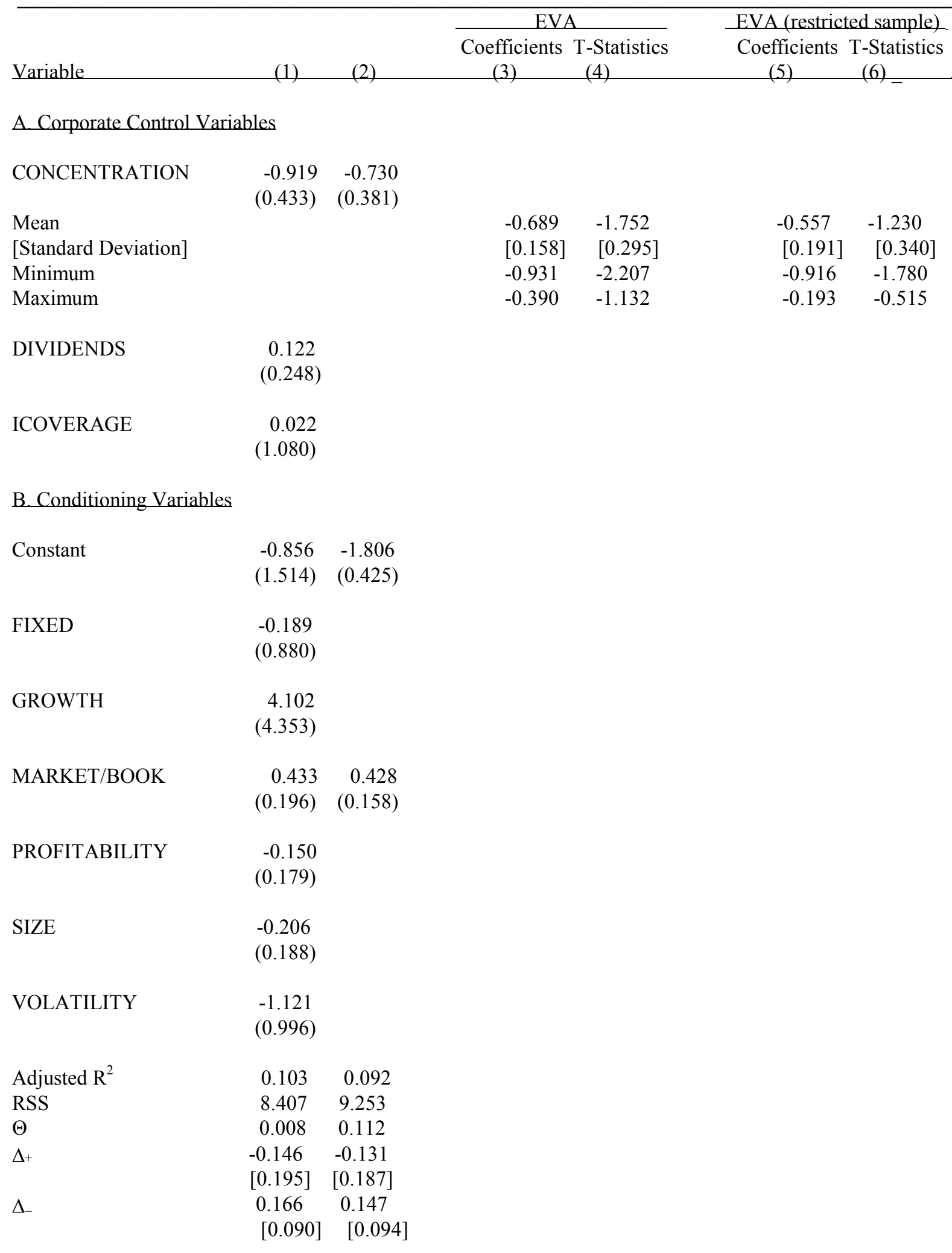


probability of bank affiliation. We assess this impact by the change in a firm's probability of being bank influenced when its CONCENTRATION variable changes. These changes are represented by $\Delta_{+}$, when CONCENTRATION

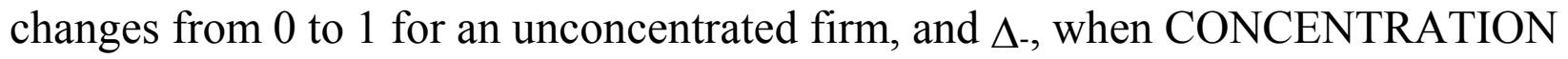
changes from 1 to 0 for a concentrated firm. ${ }^{21}$ In column 1 , the entry for $\Delta_{+}$ indicates that the probability of bank affiliation for the unconcentrated firms is initially 0.195 (the number in braces) and this probability falls sharply by -0.146 when CONCENTRATION is changed from 0 to 1 . The entry for $\Delta$-indicates that the sensitivity is approximately symmetric; for those firms who initially have concentrated ownership, the probability of bank affiliation rises by 0.166 when CONCENTRATION is changed from 1 to 0 .

Our empirical results suggesting that bank influence is a substitute control mechanism may be challenged because of the substantial cross-shareholdings by non-financial corporations. Consider a situation where Firm A has a substantial ownership interest in Firm B, and Firm A has a widely-dispersed ownership. In our dataset, Firm B would be classified as concentrated, even though its ultimate ownership is dispersed. In reviewing the work of Schreyogg and Steinmann (1981), Edwards and Fischer (1994, p. 189) conclude "...that the importance of non-financial enterprises as shareholders in Germany means that care is required when shareownership data are used to draw inferences about the significance of corporate control problems in Germany." $\quad$ Fortunately, our dataset permits us to control for the effect of cross-shareholdings by non-financial corporations. We remove those firms for which a national enterprise holds a) more than $25 \%$ of the outstanding shares and no other owner holds more than $25 \%$ or b) more than $50 \%$ of the outstanding shares (i.e., those national enterprises holding a majority or plurality (in excess of 25\%) of the outstanding shares). This exclusion reduces the

${ }^{21}$ See the notes to Table 4 for details about the computation of $\Delta_{+}$and $\Delta_{-}$. 
number of observations from 91 to 58 .

The EVA with the reduced samples is presented in columns 5 and 6 of Table 4, and offers a dramatic confirmation of the corporate control hypothesis. The mean of the distributions falls (in absolute value) from -0.689 to -0.557 . As expected given the reduction in sample size, standard deviations rise. The distributions of t-statistics are shifted toward zero with the smaller samples. Most importantly, removing the effect of cross-shareholdings has no impact on the general conclusion to be drawn from the probit estimates -- it is impossible to obtain anything other than a negative sign for any of the CONCENTRATION coefficients and these coefficients are frequently far from zero in a statistical sense.

In sum, our results point toward the interpretation that the control problems posed by the corporate form of organization are addressed by concentrated ownership or bank influence.

\section{The Profitability Hypothesis}

\subsection{Testable Implications}

The GBIM holds that there exists unique benefits associated with a bank relation. Lower charges for external finance and limits on managerial opportunism will enable firms, ceteris paribus, to earn greater profits. The profitability hypothesis is examined in terms of the following OLS specification,

$$
\text { PROFITABILITY }=\underset{+}{\underset{+}{\boldsymbol{\Phi}}\left[\mathrm{BI}: \mathrm{Z}^{\mathrm{P}}\right]+\varepsilon,}
$$

where PROFITABILITY is return on assets, equal to net income (after pension payments but before taxes) and interest expense both divided by TOTALASSETS. The conditioning variables represented by $Z^{P}$ are the same as $Z^{F}$ with the inclusion of LEVERAGE and the exclusion of PROFITABILITY and DIVIDENDS. 
LEVERAGE is included to capture a positive risk premia impounded in PROFITABILITY, and DIVIDENDS is excluded because, with relatively constant dividend payout ratios, PROFITABILITY and DIVIDENDS move very closely together. The impact of bank influence on PROFITABILITY is assessed by the coefficient on BI.

This implication is based on several auxiliary assumptions that have not received attention in the literature. For firms in a competitive industry, a favorable shift in the long-run cost curve (due to an attenuation of finance and control problems) would increase the scale of operation but have no long-run impact on profitability. Thus, it is possible for the GBIM's finance and control channels to positively impact firms, but their effects may remain undetectable by profitability equations. To generate the prediction of a positive coefficient on BI in (4), we need to impose an auxiliary assumption about noncompetitive product or factor markets or other impediments permitting a sustained level of economic profits Independent of favorable financing and control outcomes and a noncompetitive market structure, firm profitability can be negatively related to bank influence for three very different reasons (which are not mutually exclusive). First, the information advantage enjoyed by banks may permit them to exploit firms with which they are associated through excessive charges for borrowed funds or fees for a variety of services, such as underwriting securities, conducting trust and fiduciary businesses, and facilitating financial market transactions (Baums, 1993; Wenger, 1992). Second, bank influence and firm profitability can be negatively associated because of a selection effect. Firms encountering financial difficulties may become affiliated with banks, and the relative profitability of bank influenced firms will be lower. Rather than pointing toward a deleterious role, this negative profitability effect may actually highlight a 
significant value of bank affiliation. ${ }^{22}$ Third, instead of guarding shareholders' interests, banks may in fact protect management from shareholders by their positions on the supervisory board and accumulation of voting rights. Policies followed by such protected management would deviate from the profitmaximizing optimum.

To summarize the above discussion, the GBIM in isolation does not have clear implications for the relation between firm profitability and bank influence (4), which can be consistent with the following economic environments:

Positive Relation: $\quad$ Valid GBIM and noncompetitive markets;

Negative Relation: $\quad$ Firm exploitation, adverse selection, or management protection;

No Relation: $\quad$ Valid GBIM and competitive markets, or invalid GBIM.

Although the profitability test is somewhat ambiguous, a negative relation clearly rejects the GBIM.

\subsection{Empirical Results}

The relation between profitability and bank influence is examined in Table 5. The PROFITABILITY regressions in columns 1 and 2 indicate significant relations with MARKET/BOOK and LEVERAGE. For BI, the coefficients are negative and statistically significant at the $10 \%$ level in column 1 but not in column 2. When BI is interacted with the conditioning variables, the results in column 2 are statistically significant $(\Omega=0.073)$ but economically unimportant $(\Gamma$ $=-0.036)$. Bank influence is negatively related to PROFITABILITY but, on balance, this relation is not statistically or economically significant. This

${ }^{22}$ Seger (1997, Table 56) finds no evidence that bank influence is positively associated with poorly performing companies. 
Table 5: Ordinary Least Squares Regressions -- Dependent Variable: PROFITABILITY

For all but the last two rows, the entries are based on the following Ordinary Least Squares (OLS) regression model (4): PROFITABILITY $=\boldsymbol{\Phi}\left[\mathrm{BI}: \mathrm{Z}^{\mathrm{P}}\right]+\varepsilon . \boldsymbol{\Phi}[$.$] is a linear function, \varepsilon$ is a stochastic error, and $\mathrm{Z}^{\mathrm{P}}$ represents the set of conditioning variables listed in Panel $\mathrm{B}$. Column 1 uses the full set of conditioning variables; column 2 uses those conditioning variables significant at the $10 \%$ level in the initial regression. Column 5 uses the full set of conditioning variables except for CONCENTRATION. Column 6 uses the full set of conditioning variables, but excludes BI. All variables are described in Table 1. Estimated coefficients are reported in the table; standard errors are in parentheses and are heteroscedastic consistent using the technique of White (1980) with a bias correction (Davidson and MacKinnon, 1993, pp. 552-554, equation $\mathrm{HC}_{2}$ ). RSS is the residual sum of squares. The remaining two entries are based on the following OLS regression model that permits both the constant term and slope coefficients to differ for bank influenced firms: PROFITABILITY $=\boldsymbol{\Phi}\left[\mathrm{BI} * \mathrm{Z}^{\mathrm{P}}: \mathrm{Z}^{\mathrm{P}}\right]+\varepsilon . \Omega$ is the p-value for the Fstatistic testing the null hypothesis that the interaction variables, $\mathrm{BI}^{*} \mathrm{Z}^{\mathrm{P}}$, have no effect on PROFITABILITY. This statistic is distributed $\mathrm{F}(\mathrm{K}, \mathrm{N}-2 \mathrm{~K})$, where $\mathrm{K}$ is the number of conditioning variables (including the constant term). $\Gamma$ is the percentage change in PROFITABILITY with respect to an increase in $\mathrm{BI}$. For firms having $\mathrm{BI}=0, \mathrm{BI}$ is changed from 0 to 1 , and the fitted values of PROFITABILITY are computed; for firms having $\mathrm{BI}=1, \mathrm{BI}$ is changed from 1 to 0 , the fitted values of PROFITABILITY are computed, and are multiplied by -1 . $\Gamma$ equals the mean of the ratio of these fitted values divided by PROFITABILITY. $\Omega$ and $\Gamma$ measure the statistical and economic importance, respectively, of the interaction variables. Columns 3 and 4 contain the Extreme Value Analysis (EVA) using all possible combinations of the conditioning variables. Column 3 contains the mean, standard deviation, lower bound, and upper bound of the distribution of the estimated BI coefficient. Column 4 contains the same statistics for the distribution of the associated t-statistic. 
Table 5 (continued): Ordinary Least Squares Regressions -- Dependent Variable: PROFITABILITY

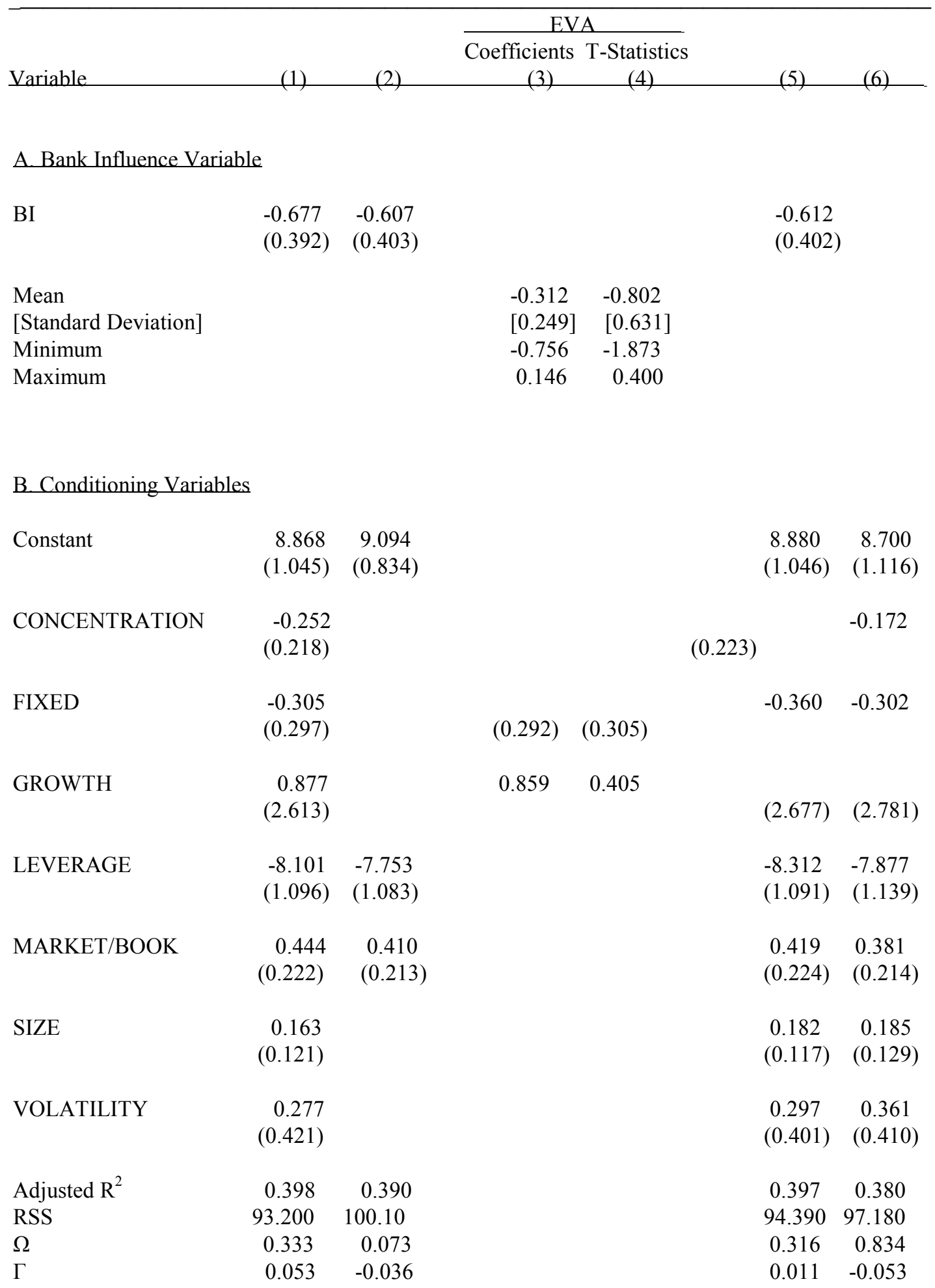


conclusion is supported by the EVAs in columns 3 and 4 of Table 5. Negative coefficients predominate, and statistical and economic significance are usually absent for BI. Bank influence is negatively related to profitability in some cases, but the relation appears fragile. More definitively, there is no evidence supporting the GBIM's positive profitability effect.

The probit results in Section 4 suggest that bank influence and concentrated ownership are substitute control mechanisms. This substitutability implies that these two control variables should have similar effects on profitability. Column 1 confirms this implication; both BI and CONCENTRATION are negative but imprecisely estimated. Further information can be obtained by reestimating equation 4 (presented in column 1) with only BI or CONCENTRATION included as a regressor along with the other conditioning variables. These results are presented in columns 5 and 6, and confirm that bank influence and ownership concentration have negative but statistically insignificant effects on profitability.

These results for ownership concentration are related to the recent and important work on legal structures and corporate governance developed in a series of papers by La Porta, Lopez-de-Silanes, Shleifer, and Vishny. ${ }^{23}$ In their framework, ownership concentration may enhance performance by reducing the managerial agency costs that arise with the separation of management and finance. These costs are particularly likely to occur in Germany with its relatively weak legal protections of equity investors. However, it is also recognized that the private benefits of control may also rise with concentrated ownership to the detriment of firm performance. The results in Table 5 suggest either that ownership concentration does not convey the above benefit and cost or that they

${ }^{23}$ See La Porta, Lopez-de-Silanes, Shleifer, and Vishny (1998) and Shleifer and Vishny (1997) and references therein. 
approximately cancel.

\section{Summary and Conclusions}

This study has examined the German Bank Influence Model (GBIM) with a unique dataset and a focus on the fragility/sturdiness of inferences. Three implications of the GBIM have been assessed.

First, do bank influenced firms enjoy lower finance costs? German banks allegedly supply finance relatively cheaply because of their technical expertise and superior information. In addition to this direct finance channel, we also examined a certification channel that may lower finance costs indirectly. Our results suggested that finance costs are not lower for firms affiliated with banks.

Second, is bank influence a solution to control problems? By combining superior information and consolidated power, banks are allegedly well-positioned to consult, monitor or discipline management. A sizeable equity stake may create substantial incentives to exercise corporate control. Bank influence and concentrated ownership were negatively related, which suggested that they are substitute means for controlling corporations.

Third, do bank influenced firms enjoy higher profitability? The favorable financing and control outcomes associated with the GBIM implies a favorable shift in the long-run cost curve and an increase in profitability provided the firms operate in noncompetitive markets. This hypothesis is not supported in the current study. In contrast to Cable (1985), Gorton and Schmid (2000), and Lehmann and Weigand (2000), we do not find a significant positive relation between bank influence and profitability.

Our empirical results do not lend much support to the GBIM and, while deep structural links have not been uncovered, they permit us to draw a preliminary sketch of an alternative model of the German system of corporate control (though additional interpretations are possible). Control dilemmas are 
omnipresent, and firm owners address this problem by choosing a concentrated ownership structure or a bank affiliation (Table 4). ${ }^{24}$ Banks must be compensated for the resources employed in creating value for their client firms. Such compensation can take the form of fees for various services or charges for borrowed funds that are above market levels. The empirical results in Table 2 indicate that bank affiliated firms do not hold greater amounts of bank debt, and these weakly negative relations are compatible with the following scenario: the firm participates in a loan market substantially controlled by its primary bank, the bank offers its profit-maximizing price of debt, and bank affiliated firms respond by borrowing less than independent firms facing lower loan rates. Relatively expensive bank interest charges and service fees survive in equilibrium because of the compensating benefits from the resolution of control problems enhancing economic performance. On balance, there is no net effect on profitability relative to independent firms (Table 5) as the benefits of control are counterbalanced by the inflated costs of banking services. ${ }^{25}$ This equilibrium is sustainable provided banks continue to be effective monitors, a role questioned recently because of several prominent failures of corporate control.

The results presented in this study and the above sketch of the German system of finance and control suggests several directions for future research. Demsetz and Lehn (1985, United States) and Prowse (1992, Japan) have shown that ownership patterns respond to the economic incentives for control. Our finding on corporate control substitutability raises the further question as to which

\footnotetext{
${ }^{24}$ This conclusion is consistent the evidence in Kaplan (1994), who finds that, for German firms, the relation between management board turnover and firm performance is independent of bank affiliation. He concludes that "...one plausible explanation is that all firms are subject to similar monitoring technologies" (p. 144).

${ }^{25}$ A similar conclusion about bank-firm relations in Japan is reached by Weinstein and Yafeh (1998).
} 
policy and non-policy factors determine the type of control mechanism used in Germany.

An additional issue is the purported role played by banks assisting firms in financial distress. This important function has been documented by Hoshi, Kashyap, and Scharfstein (1990) in Japan. Whether German banks function in a similar supportive manner remains an important open question, especially since active support of financially distressed firms would impact the interpretation of the bank-profitability relation. Further examination of these issues should yield a deeper understanding of the structural characteristics of the German economy and the general nature of finance and governance mechanisms. 


\section{Appendix: List Of The 91 German Firms Drawn From The Bonn Database}

The number in column 1 is the firm's identifier in this list. The number in column 2 is the firm's identifier in the Bonn Database.

\begin{tabular}{lll}
1 & 2 & AKZO FASER AG \\
2 & 540 & ALEXANDERWERK AG REMSCHEID \\
3 & 541 & ALLWEILER AG \\
4 & 522 & AMIRA VERWALTUNGS AG \\
5 & 145 & ANDREAE- NORIS ZAHN AG \\
6 & 68 & AUDI AG \\
7 & 542 & BADENWERK AG \\
8 & 28 & BALCKE-DUERR AG \\
9 & 7 & BASF AG \\
10 & 32 & BAYER AG \\
11 & 12 & BAYERISCHE MOTORENWERKE AG \\
12 & 10 & BEIERSDORF AG \\
13 & 549 & BERLINER KINDL BRAUEREI AG \\
14 & 122 & BILFINGER + BERGER BAUAKTIENGESELLSCHAFT \\
15 & 555 & BRAUEREI CLUSS \\
16 & 558 & BRAUNSCHWEIGISCHE MASCHINENBAUANSTALT \\
17 & 120 & BREMER VULKAN AG \\
18 & 561 & BREMER WOLL- KAEMMEREI AG \\
19 & 17 & CASELLA AG \\
20 & 22 & CONTINENTAL GUMMI-WERKE AG \\
21 & 132 & DEUTSCHE SPEZIALGLAS AG \\
22 & 26 & DEUTSCHE TELEPHONWERKE UND KABELINDUSTRIE AG \\
23 & 127 & DIDIER - WERKE AG \\
24 & 574 & DORTMUNDER ACTIEN BRAUEREI AG \\
25 & 52 & DORTMUNDER RITTERBRAUEREI AG \\
26 & 107 & DYCKERHOFF AG \\
27 & 324 & ELSFLETHER WERFT AG \\
28 & 547 & ENERGIEVERSORGUNG OBERFRANKEN AG \\
29 & 581 & ENERGIEVERSORGUNG OSTBAYERN AG \\
30 & 584 & ERLUS BAUSTOFFWERKE AG \\
31 & 585 & ERSTE KULMBACHER ACTIEN BRAUEREI AG \\
32 & 36 & FORD-WERKE AG \\
33 & 587 & FRAENKISCHES UEBERLANDWERK AG \\
34 & 39 & GEHE AG \\
35 & 41 & GOLDSCHMIDT, TH. AG \\
36 & 160 & GRUENZWEIG + HARTMANN UND GLASFASER AG \\
37 & 42 & GUANO-WERKE AG \\
38 & 46 & HAGEDA AG \\
39 & 130 & HARTMANN \& BRAUN AG \\
40 & 5 & HASEN-BRAEU AG \\
41 & 152 & HEIDELBERGER ZEMENT AG \\
42 & 166 & HEIN, LEHMANN AG \\
43 & 48 & HILGERS AG \\
44 & 97 & HOCHTIEF AG \\
& & \\
\hline & & \\
& &
\end{tabular}


\begin{tabular}{lll}
45 & 33 & HOECHST AG \\
46 & 598 & HOFBRAUHAUS WOLTERS AG \\
47 & 49 & HOLSTEN BRAUEREI AG \\
48 & 140 & HUTSCHENREUTHER AG \\
49 & 600 & ISAR- AMPERWERKE AG \\
50 & 551 & KARSTADT AG \\
51 & 254 & KEMPINSKI AG \\
52 & 147 & KERAMAG KERAMISCHE WERKE AG \\
53 & 20 & KLOECKNER-HUMBOLDT-DEUTZ AG \\
54 & 128 & KOLB \& SCHUELE AG \\
55 & 169 & KRAUSS-MAFFI AG \\
56 & 125 & KSB KLEIN, SCHANZLIN \& BECKER AG \\
57 & 258 & KUEHLHAUS ZENTRUM AG \\
58 & 277 & KULMBACHER REICHELBRAEU AG \\
59 & 259 & KUPFERBERG, CHR., ADALBERT + CO. KGAA \\
60 & 58 & LECH ELEKTRIZITAETSWERKE AG \\
61 & 171 & LEONISCHE DRAHTWERKE AG \\
62 & 69 & LINDE AG \\
63 & 262 & MAIN - KRAFTWERKE AG \\
64 & 40 & MARKT- UND KUEHLHALLEN AG \\
65 & 179 & MASCHINENFABRIK MUELLER-WEINGARTEN AG \\
66 & 268 & MITTELSCHWAEBISCHE UEBERLANDZENTRALE AG \\
67 & 182 & MUEHLE RUENINGEN AG \\
68 & 344 & NECKARWERKE ELEKTRIZITAETSVERSORGUNGS- AG \\
69 & 153 & NORDCEMENT AG \\
70 & 126 & O \& K ORENSTEIN \& KOPPEL AG \\
71 & 71 & PARKBRAUEREI AG PIRMASENS-ZWEIBRUECKEN \\
72 & 501 & PFERSEE KOLBERMOOR AG \\
73 & 102 & PHOENIX AG \\
74 & 280 & RHENAG RHEINISCHE ENERGIE AG \\
75 & 19 & RIETER INGOLSTADT SPINNEREIMASCHINENBAU AG \\
76 & 63 & SALAMANDER AG \\
77 & 284 & SEKTKELLREI SCHLOSS WACHENHEIM AG \\
78 & 90 & SPINNSTOFF FABRIK ZEHLENDORF AG \\
79 & 92 & SUED-CHEMIE AG \\
80 & 105 & TUCHER BRAEU AG \\
81 & 511 & UEBERLANDWERK UNTERFRANKEN AG \\
82 & 513 & UNIVERSITAETSDRUCKEREI H. STUERTZ AG \\
83 & 65 & VEREINIGTE DEUTSCHE NICKELWERKE AG \\
84 & 525 & VEREINIGTE ELEKTRIZITAETSWERKE WESTFALEN AG \\
85 & 96 & VEREINIGTE FILZFABRIKEN GIENGEN AG \\
86 & 517 & VGT AG \\
87 & 296 & WESTAG \& GETALIT AG \\
88 & 527 & WILKENS BREMER SILBERWAREN AG \\
89 & 143 & WMF WUERTTEMBERGISCHE METALLWARENFABRIK AG \\
90 & 529 & WOLLDECKENFABRIK WEIL DER STADT AG \\
91 & 531 & ZEAG ZEMENTWERK LAUFFEN - ELEKTRIZITAETSWERK HEILBRONN AG \\
& & \\
\hline 5 &
\end{tabular} 


\section{References}

Baums, Theodor, "The German Banking System and Its Impacts on Corporate Finance and Governance," Institut für Handels-und Wirtschaftsrecht, Universität Osnabrück (1993).

Baums, Theodor, "Universal Banks and Investment Companies in Germany," in Anthony Saunders and Ingo Walter (eds.), Universal Banking: Financial System Design Reconsidered (Chicago: Irwin, 1996), 124-160. A related article is Baums, Theodor, and Fraune, Christian, "Institutionelle Anleger und Publikumsgesellschaft: Eine empirische Untersuchung," Die Aktien Gesellschaft 40 (1995), 97-112.

Bernanke, Benjamin S., "Credit In The Macroeconomy," Federal Reserve Bank of New York Quarterly Review 18 (Spring 1993), 50-70.

Brennan, Michael J., "Corporate Finance Over The Past 25 Years," in Michael J. Brennan (ed.), Empirical Corporate Finance: Volume I (Aldershot and Lyme, NH, Edward Elgar, 2001).

Cable, John, "Capital Market Information and Industrial Performance: The Role of West German Banks," The Economic Journal 95 (March 1985), 118-132.

Commerzbank, Wer Gehört Zu Wem, Frankfurt (various annual issues).

Corbett, Jenny, and Jenkinson, Tim, "German Investment Financing: An International Comparison," in Stanley W. Black and Mathias Moersch (eds.), Competition and Convergence: The German and American Models (Amsterdam: Elsevier Science Publishers, 1998), 101-117.

Cosh, Andy, and Guest, Paul, "The Long-Run Performance of Hostile Takeovers: U.K. Evidence," ESRC Centre for Business Research, University of Cambridge Working Paper No. 215 (September 2001).

Davidson, Russell, and MacKinnon, James G., Estimation and Inference in Econometrics (New York: Oxford University Press, 1993).

Deeg, Richard E., "Banks and the State in Germany: The Critical Role of Subnational Institutions in Economic Governance," Unpublished Ph.D. Dissertation, Department of Political Science, M.I.T. (June 1992).

Demsetz, Harold, and Lehn, Kenneth, "The Structure of Corporate Ownership: Causes and Consequences," Journal of Political Economy 93 (December 1985), 1155-1177.

Easterbrook, Frank, "Two Agency-Cost Explanations of Dividends," American Economic Review 74 (September 1984), 650-659.

Edwards, Jeremy, and Fischer, Klaus, Banks, Finance and Investment in Germany (Cambridge and New York: Cambridge University Press (for the Centre For Economic Policy Research), 1994). 
Elston, Julie Ann, "Banks, Finance and Investment in Germany: A Review Article", Small Business Economics 7 (1995), 1-5.

Federal Statistics Office, Statistisches Jahrbuch, Wiesbaden (various issues).

Franks, Julian, and Mayer, Colin, "Hostile Takeovers and the Correction of Managerial Failure," Journal of Financial Economics 40 (1996), 163-181.

Gessler Commission, "Grundsatzfragen der Kreditwirtschaft (Basic Questions Pertaining to the Credit Economy)," Schriftenreihe des Bundesministeriums der Finanzen 28 (1979).

Gorton, Gary, "Review of 'Banks, Finance and Investment in Germany'," Journal of Economic Literature 33 (September 1995), 1351-1353.

Gorton, Gary, and Schmid, Frank A., "Universal Banking and The Performance of German Firms," Journal Of Financial Economics 58 (October/November 2000), 29-80.

Grossman, Sanford, and Hart, Oliver, "Corporate Financial Structure and Managerial Incentives," in J. McCall (ed.), The Economics of Information and Uncertainty (Chicago: University of Chicago Press, 1982), 123-155.

Harris, Milton, and Raviv, Artur, "Capital Structure and the Information Role of Debt," Journal of Finance 45 (1990), 321-350.

Harris, Milton, and Raviv, Artur, "The Theory of Capital Structure," Journal of Finance 46 (1991), 297-355.

Hart, Oliver, "Corporate Governance: Some Theory and Implications," The Economic Journal 105 (May 1995), 678-689.

Hellwig, Martin F., "Banking, Financial Intermediation and Corporate Finance," in Alberto Giovannini and Colin Mayer (eds.) European Financial Integration (Cambridge and New York: Cambridge University Press, 1991), 35-63.

Hodder, James E., and Tschoegl, Adrian E., "Corporate Finance In Japan," Center for Economic Policy Research Working Paper No. 279 (January 1992).

Hoppenstedt, Aktienführer, annual issues, 1965-1990 (Darmstadt: Verlag Hoppenstedt, 1990).

Hoppenstedt, Handbuch der Aktiengesellschaften, Annual Issues, 1965-1990 (Darmstadt: Verlag Hoppenstedt, 1990).

Hoshi, Takeo, Kashyap, Anil, and Scharfstein, David. "The Role of Banks in Reducing the Costs of Financial Distress in Japan." Journal of Financial Economics 27 (1990), 67-88. 
Hubbard, R. Glenn, "Capital-Market Imperfections and Investment," Journal of Economic Literature 36 (March 1998), 193-225.

James, Christopher, "Some Evidence on the Uniqueness of Bank Loans," Journal of Financial Economics 19 (1987), 217-236.

Jenkinson, Tim, and Ljungqvist, Alexander, "The Role of Hostile Stakes in German Corporate Governance," Journal of Corporate Finance 7 (2001), 397-446.

Jensen, Michael C., "Agency Costs of Free Cash Flow, Corporate Finance, and Takeovers," American Economic Review 76 (May 1986), 323-329.

Kaplan, Steven N., "Top Executives, Turnover, and Firm Performance in Germany," Journal of Law and Economic Organization 10 (April 1994), 142-159.

Kester, W. Carl, "Governance, Contracting, and Investment Horizons: A Look At Japan and Germany," Journal of Applied Corporate Finance 5 (1992), 83-98.

Krummel, Hans-Jacob, "German Universal Banking Scrutinized: Some Remarks Concerning the Gessler Report," Journal of Banking and Finance 4 (1980).

Leamer, Edward E., "Let's Take the Con Out of Econometrics," American Economic Review 73 (March 1983), 31-43.

Lehmann, Erik, and Weigand, Jürgen, "Does the Governed Corporation Perform Better?: Governance Structures and Corporate Performance in Germany," European Finance Review 4 (2000), pp. 157-195.

Lindberg, Leon N., Campbell, John L., and Hollingsworth, J. Rogers, "Economic Governance and the Analysis of Structural Change in the American Economy," in John L. Campbell, J. Rogers Hollingsworth, and Leon N. Lindberg (eds.) Governance of the American Economy (Cambridge and New York: Cambridge University Press, 1991).

La Porta, R., Lopez-de-Silanes, F., Shleifer, A., and Vishny, R.W. (1998), 'Law and Finance,' Journal of Political Economy 106, 1113-1155.

Lummer, Scott L., and McConnell, John J., "Further Evidence on the Bank Lending Process and the Capital Market Responses to Bank Loan Agreements," Journal of Financial Economics 25 (1989), 99-122.

Martin, J. and McConnell, J.J., "Corporate Performance, Corporate Takeovers and Management Turnover," Journal of Finance 46 (June 1991), 671-687.

Mayer, Colin, "Financial Systems, Corporate Finance, and Economic Development," in R. Glenn Hubbard (ed.), Asymmetric Information, Corporate Finance, and Investment (Chicago: University of Chicago Press (for the NBER), 1990), 307-332. 
Mülbert, Peter O., "Bank Equity Holdings in Non-Financial Firms and Corporate Governance: The Case of German Universal Banks," in Klaus J. Hopt, Hideki Kanada, Mark J. Roe, Eddy Wymeersch, and Stefan Prigge (eds.), Comparative Corporate Governance - The State of the Art and Emerging Research (Oxford: Clarendon, 1998), 445-497.

Perlitz, Manfred, and Seger, Frank, "The Role of Universal Banks in German Corporate Governance," Business \& The Contemporary World 6 (1994), 49-67.

Pesaran, M. Hashem, and Smith, Ron, "Estimating Long-Run Relationships From Dynamic Heterogeneous Panels," Journal of Econometrics 68 (1995), 79-113.

Prowse, Stephen D., "The Structure of Corporate Ownership in Japan," The Journal of Finance 47 (July 1992), 1121-1140.

Rajan, Raghuram G., "Insiders and Outsiders: The Choice Between Informed and Arm'sLength Debt," The Journal of Finance 47 (September 1992), 1367-1400.

Roe, Mark J., Strong Managers, Weak Owners: The Political Roots of American Corporate Finance (Princeton: Princeton University Press, 1994).

Roy, William G., Socializing Capital: The Rise of the Large Industrial Corporation in America (Princeton: Princeton University Press, 1997).

Sable, Charles F., Griffin, J. and Deeg, Richard E., "Making Money Talk: Towards a New Debtor-Creditor Relation in German Banking," M.I.T. (1993).

Schreyogg, G, and Steinmann, H., "Zur Trennung von Eigentum und Verfugungsgewalt Eine Empirische Analyse der Beteiligungsverhaltnisse in Deutschen Grossunternehmen," Zeitschrift für Betriebswirtschaft 51 (1981), 533-556.

Seger, Frank, "Banken, Erfolg und Finanzierung - Eine Analyse für deutsche Industrieunternehmen," Ph.D. dissertation, Mannheim (Wiesbaden: Gabler Verlag, 1997).

Sharpe, Steven, "Asymmetric Information, Bank Lending and Implicit Contracts: A Stylized Model of Customer Relationships," The Journal of Finance 45 (1990), 1069-1087.

Shleifer, Andrei, and Vishny, Robert W., "A Survey of Corporate Governance," The Journal of Finance 52 (June 1997), 737-783.

Smith, Eric Owen, The German Economy (London and New York: Routledge, 1994).

Stiglitz, Joseph E., "Credit Markets and the Control of Capital," Journal of Money, Credit and Banking 17 (May 1985), 133-152. 
Wenger, Ekkehard, "Universalbankensystem und Depotstimmrecht," Schriften des Vereins fur Socialpolitik (Der Markt fur Unternehmenskontrollen) Neue Folge Band 214 (1992), 73-103.

Wenger, Ekkehard, and Kaserer, Christoph, "The German System of Corporate Governance - A Model Which Should Not Be Imitated" in Stanley W. Black and Mathias Möersch (eds.), Competition and Convergence: The German and American Models (Amsterdam: Elsevier Science Publishers, 1998), 41-78.

Weinstein, David E., and Yafeh, Yishay, "On the Costs of a Bank Centered Financial System: Evidence from the Changing Main Bank Relations in Japan," The Journal of Finance 53 (1998), 635-672.

White, Halbert, "A Heteroskedasticity-Consistent Covariance Matrix Estimator and a Direct Test for Heteroskedasticity," Econometrica 48 (May 1980), 817-838.

Zysman, John, Governments, Markets, and Growth: Financial Systems and the Politics of Industrial Change (Ithaca: Cornell University Press, 1983). 


\section{CESifo Working Paper Series}

(for full list see www.cesifo.de)

1009 Marco Runkel, Optimal Contest Design when the Designer's Payoff Depends on Competitive Balance, August 2003

1010 Donald O. Parsons, Torben Tranaes and Helene Bie Lilleør, Voluntary Public Unemployment Insurance, August 2003

1011 Rüdiger Pethig and Andreas Wagener, Profit Tax Competition and Formula Apportionment, August 2003

1012 Johan Willner, Privatisation and Public Ownership in Finland, August 2003

1013 Seppo Kari and Jouko Ylä-Liedenpohja, Taxation and Valuation of International Real Investments, August 2003

1014 James Heckman, Rosa Matzkin and Lars Nesheim, Simulation and Estimation of Hedonic Models, August 2003

1015 Biswa N. Bhattacharyay, Towards a Macro-Prudential Leading Indicators Framework for Monitoring Financial Vulnerability, August 2003

1016 J. Stephen Ferris and Stanley L. Winer, Searching for Keynes: With Application to Canada, 1870-2000, August 2003

1017 Massimo Bordignon, Luca Colombo and Umberto Galmarini, Fiscal Federalism and Endogenous Lobbies' Formation, August 2003

1018 Annette Alstadsæter, The Dual Income Tax and Firms' Income Shifting through the Choice of Organizational Form and Real Capital Investments, August 2003

1019 Peter Fredriksson and Bertil Holmlund, Optimal Unemployment Insurance Design: Time Limits, Monitoring, or Workfare?, August 2003

1020 Kashif S. Mansori, Following in their Footsteps: Comparing Interest Parity Conditions in Central European Economies to the Euro Countries, August 2003

1021 Christoph Borgmann and Matthias Heidler, Demographics and Volatile Social Security Wealth: Political Risks of Benefit Rule Changes in Germany, August 2003

1022 Kjell Erik Lommerud, Bjørn Sandvik and Odd Rune Staume, Good Jobs, Bad Jobs and Redistribution, August 2003

1023 Patrick Karl O'Brien, The Governance of Globalization: The Political Economy of Anglo-American Hegemony, 1793-2003, September 2003 
1024 Antonio Ciccone and Giovanni Peri, Skills' Substitutability and Technological Progress: U.S. States 1950-1990, September 2003

1025 Bjørn Sandvik, Optimal Taxation and Normalisations, September 2003

1026 Massimo Bordignon and Gilberto Turati, Bailing Out Expectations and Health Expenditure in Italy, September 2003

1027 José A. Herce, Namkee Ahn, Ricard Génova, and Joaquín Pereira, Bio-Demographic and Health Aspects of Ageing in the EU, September 2003

1028 John Komlos and Marieluise Baur, From the Tallest to (One of) the Fattest: The Enigmatic Fate of the American Population in the $20^{\text {th }}$ Century, September 2003

1029 Stefan Napel and Mika Widgrén, Bargaining and Distribution of Power in the EU's Conciliation Committee, September 2003

1030 Kai Li and Dale J. Poirier, Relationship Between Maternal Behavior During Pregnancy, Birth Outcome, and Early Childhood Development: An Exploratory Study, September 2003

1031 Ivar Ekeland, James J. Heckman, and Lars Nesheim, Identifcation and Estimation of Hedonic Models, September 2003

1032 Kjetil Bjorvatn and Alexander W. Cappelen, Decentralization and the Fate of Minorities, September 2003

1033 Lars-Erik Borge and Jørn Rattsø, The Relationships Between Costs and User Charges: The Case of a Norwegian Utility Service, September 2003

1034 Maureen Were and Nancy N. Nafula, An Assessment of the Impact of HIV/AIDS on Economic Growth: The Case of Kenya, September 2003

1035 A. Lans Bovenberg, Tax Policy and Labor Market Performance, September 2003

1036 Peter Birch Sørensen, Neutral Taxation of Shareholder Income: A Norwegian Tax Reform Proposal, September 2003

1037 Roberta Dessi and Sheilagh Ogilvie, Social Capital and Collusion: The Case of Merchant Guilds, September 2003

1038 Alessandra Casarico and Carlo Devillanova, Capital-skill Complementarity and the Redistributive Effects of Social Security Reform, September 2003

1039 Assaf Razin and Efraim Sadka, Privatizing Social Security Under Balanced-Budget Constraints: A Political-Economy Approach, September 2003

1040 Michele Moretto, Paolo M. Panteghini, and Carlo Scarpa, Investment Size and Firm's Value under Profit Sharing Regulation, September 2003 
1041 A. Lans Bovenberg and Peter Birch Sørensen, Improving the Equity-Efficiency Tradeoff: Mandatory Savings Accounts for Social Insurance, September 2003

1042 Bas van Aarle, Harry Garretsen, and Florence Huart, Transatlantic Monetary and Fiscal Policy Interaction, September 2003

1043 Jerome L. Stein, Stochastic Optimal Control Modeling of Debt Crises, September 2003

1044 Thomas Stratmann, Tainted Money? Contribution Limits and the Effectiveness of Campaign Spending, September 2003

1045 Marianna Grimaldi and Paul De Grauwe, Bubbling and Crashing Exchange Rates, September 2003

1046 Assar Lindbeck and Dennis J. Snower, The Firm as a Pool of Factor Complementarities, September 2003

1047 Volker Grossmann, Firm Size and Diversification: Asymmetric Multiproduct Firms under Cournot Competition, September 2003

1048 Dan Anderberg, Insiders, Outsiders, and the Underground Economy, October 2003

1049 Jose Apesteguia, Steffen Huck and Jörg Oechssler, Imitation - Theory and Experimental Evidence, October 2003

1050 G. Abío, G. Mahieu and C. Patxot, On the Optimality of PAYG Pension Systems in an Endogenous Fertility Setting, October 2003

1051 Carlos Fonseca Marinheiro, Output Smoothing in EMU and OECD: Can We Forego Government Contribution? A Risk Sharing Approach, October 2003

1052 Olivier Bargain and Nicolas Moreau, Is the Collective Model of Labor Supply Useful for Tax Policy Analysis? A Simulation Exercise, October 2003

1053 Michael Artis, Is there a European Business Cycle?, October 2003

1054 Martin R. West and Ludger Wößmann, Which School Systems Sort Weaker Students into Smaller Classes? International Evidence, October 2003

1055 Annette Alstadsaeter, Income Tax, Consumption Value of Education, and the Choice of Educational Type, October 2003

1056 Ansgar Belke and Ralph Setzer, Exchange Rate Volatility and Employment Growth: Empirical Evidence from the CEE Economies, October 2003

1057 Carsten Hefeker, Structural Reforms and the Enlargement of Monetary Union, October 2003

1058 Henning Bohn and Charles Stuart, Voting and Nonlinear Taxes in a Stylized Representative Democracy, October 2003 
1059 Philippe Choné, David le Blanc and Isabelle Robert-Bobée, Female Labor Supply and Child Care in France, October 2003

1060 V. Anton Muscatelli, Patrizio Tirelli and Carmine Trecroci, Fiscal and Monetary Policy Interactions: Empirical Evidence and Optimal Policy Using a Structural New Keynesian Model, October 2003

1061 Helmuth Cremer and Pierre Pestieau, Wealth Transfer Taxation: A Survey, October 2003

1062 Henning Bohn, Will Social Security and Medicare Remain Viable as the U.S. Population is Aging? An Update, October 2003

1063 James M. Malcomson, Health Service Gatekeepers, October 2003

1064 Jakob von Weizsäcker, The Hayek Pension: An efficient minimum pension to complement the welfare state, October 2003

1065 Joerg Baten, Creating Firms for a New Century: Determinants of Firm Creation around 1900, October 2003

1066 Christian Keuschnigg, Public Policy and Venture Capital Backed Innovation, October 2003

1067 Thomas von Ungern-Sternberg, State Intervention on the Market for Natural Damage Insurance in Europe, October 2003

1068 Mark V. Pauly, Time, Risk, Precommitment, and Adverse Selection in Competitive Insurance Markets, October 2003

1069 Wolfgang Ochel, Decentralising Wage Bargaining in Germany - A Way to Increase Employment?, November 2003

1070 Jay Pil Choi, Patent Pools and Cross-Licensing in the Shadow of Patent Litigation, November 2003

1071 Martin Peitz and Patrick Waelbroeck, Piracy of Digital Products: A Critical Review of the Economics Literature, November 2003

1072 George Economides, Jim Malley, Apostolis Philippopoulos, and Ulrich Woitek, Electoral Uncertainty, Fiscal Policies \& Growth: Theory and Evidence from Germany, the UK and the US, November 2003

1073 Robert S. Chirinko and Julie Ann Elston, Finance, Control, and Profitability: The Influence of German Banks, November 2003 